\title{
Hukukun Üstünlüğü Bakımından Türkiye’nin Avrupa Birliği Karnesi: 10-11 Aralık 1999 Helsinki Zirvesi Sonrası Dönem Üzerine Bir İnceleme
}

\section{The European Union Report of Turkey in the Context the Rule of Law: A Review on the Period Following the Helsinki Summit on 10-11 December, 1999}

\author{
Yahya Demirkanoğlu ${ }^{\mathrm{a}, *}$ \\ ${ }^{a}$ Dr. Öğr. Üyesi, Bitlis Eren Üniversitesi, İktisadi ve İdari Bilimler Fakültesi, Kamu Yönetimi Bölümü, 13100, Bitlis/Türkiye. \\ ORCID: 0000-0002-0219-3657
}

\section{MAKALE BILGGISİ}

Makale Geçmişi:

Başvuru tarihi: 01 Temmuz 2020

Düzeltme tarihi: 06 Ekim 2020

Kabul tarihi: 14 Ekim 2020

\section{Anahtar Kelimeler:}

Avrupa Birliği

Helsinki Zirvesi

Hukukun Üstünlüğü

İnsan Hakları

Türkiye

\section{ÖZ}

Bu çalışmada, 10-11 Aralık 1999 Helsinki Zirvesi sonrasında Türkiye'de hukuk devleti ekseninde yapılan yasal ve yapısal dönüşümlerin, Avrupa Birliği Müktesebatına uyum bağlamında ele alınması amaçlanmıştır. Bu amaçla sürdürülen çalışmada, öncelikle hukuk devletinin kavramsal çerçevesi ele alınmıştır. Akabinde ekonomik temelden siyasal zemine eksen kayması yaşayan Avrupa Birliği'nin birlik oluşturma süreci değerlendirilmiştir. Daha sonra da Türkiye-Avrupa Birliği ilişkilerinin tarihsel uğrakları ele alınarak, çalışmanın sorunsalı olan Helsinki Zirvesi’nin ardından yaşanan dönüşüm, Avrupa Birliği üyelik koşulları açısından incelenmiştir. Türkiye adaylık statüsü elde ettiği dönemden sonra hukukun üstünlügü noktasında yasal ve yapısal alana taalluk eden önemli adımlar atmıştır. Ancak 2014 yılından sonra yaşanan olumsuz gelişmeler nedeniyle Avrupa Birliği Türkiye'yi eleştirmeye başlamıştır. Böylece ilerleme raporlarının ilk yıllarındaki olumlu hava, yerini yoğun eleştirilere bırakmıştır.

\section{A B S T R A C T}

In this study, the legal and structural transformations on the axis of the state of law in Turkey after the Helsinki Summit on 10-11 December 1999 were intended to examine in the context of compliance to the European Union Acquis. For this purpose, the conceptual framework of the rule of law was primarily addressed. Subsequently, the process of unity of the European Union experiencing an axis shift from the economic base to the political ground was evaluated. Then the transformation after the Helsinki Summit, which is the problematic of the study, has been examined in terms of the conditions of the European Union by considering historical moments of the Turkey-European Union relations. After the period in whichTurkey had taken candidacy status, the country took important steps in terms of legal and structural sphere at the point of rule of law. However, the European Union has criticized Turkey for their experienced negative developments after 2014. Thus, the positive atmosphere in the first years of the progress reports has been replaced by intense criticism.

\section{The European Union}

The Helsinki Summit

The Rule of Law

Human Rights

Turkey devleti ya da çoğu zaman onun nasıl işlediğini açıklayan hukukun üstünlüğü kavramı ile kastedilen, hukuk kurallarının hâkim olduğu devlette hem insanların, hem de devletin sınırlarının net bir şekilde tanımlanmasıdır. Böylece vatandaşlar kendi yeteneklerini geliştirme noktasında sınırlarını bilmektedirler. $\mathrm{Bu}$ anlamda hukuk devletinin vatandaşlar açısından önemli bir yönü, kişi hak

\footnotetext{
*Sorumlu yazar/Corresponding author

e-posta: yahyadmrkngl@hotmail.com
} 
ve özgürlüklerinin temel düzenlemeler aracılığıyla güvence altına alınmasıdır.

Tarihsel süreç içerisinde belirli bir kişi, azınlık, ideoloji veya zaman zaman çoğunluğun keyfi uygulamalarının insanların temel hak ve özgürlükleri noktasında tahribata neden olan yaklaşımlar içerisinde oldukları tecrübe edilmiştir. Yaşanan iki dünya savaşı ve uzun süre devam eden Soğuk Savaş yılları, insanların temel haklarını algılama noktasında büsbütün olmasa da birçok açıdan ortak sayılabilecek algının oluşmasını sağlamıştır. Böylece temel hak ve özgürlükler konusu hem ulus devletlerin, hem de uluslararası düzeyde bazı girişimlerin başlıca gündemi haline gelmiştir.

Avrupa Birliği $(\mathrm{AB})$, insan hakları ve hukukun üstünlüğü konusunda uluslararası düzeyde önemli kararları bulunan bir yapılanmadır. Birlik ilk olarak ekonomik temelde kurulsa da zaman içerisinde siyasi tutumlarda ortak tavır geliştiren bir yapıya evirilmiş, hukukun üstünlüğü ve insan hakları gibi kavramlar temel ilkeler olarak benimsenmiştir. İlk kurulduğunda altı ülkeden oluşan Topluluk, süreç içinde 27 ülkenin yer aldığı birliğe dönüşmüştür. Türkiye de öteden beri Birlik içinde yer bulmaya çalışsa da çeşitli engellerle katılım gerçekleştirememiştir. $\mathrm{Bu}$ girişimlerden en önemlisi çalışmanın konusu olan Türkiye'nin aday ülke statüsü elde ettiği 1999 yılında gerçekleştirilen Helsinki Zirvesi'dir. Üyelik süreci boyunca insan hakları başta olmak üzere, hukuk devletinin gereklerini ihtiva eden birçok yasal ve yapısal reformlar zirve sonrası gerçekleştirilmiştir.

Çalışmanın amacını bu reformların, diğer bir ifadeyle hukukun üstünlüğü konusunda Türkiye'nin gerçekleştirdiği yasal ve yapısal düzenlemelerin, $\mathrm{AB}$ üyelik koşulları açısından değerlendirilmesi teşkil etmektedir. Çalışmanın ilk bölümünde, hukuk devleti kavramsal olarak ele alınacaktır. İkinci bölümde ekonomik temelde örgütlenen AB'nin siyasal bir yapıya dönüşmesi incelenecektir. Üçüncü bölümde Türkiye'nin $\mathrm{AB}$ süreci kısaca değerlendirilecektir. Son bölümde, hukukun üstünlüğüne ilişkin yapılan yasal ve kurumsal düzenlemelerin AB'nin beklenti düzeyini karşılayıp karşılamadığı analiz edilecektir.

\section{Hukuk Devleti ya da Hukukun Üstünlüğü Üzerine}

Hukukun demokratik ve meşru özelliği ile toplumun geneline hizmet eden (Atmaca ve Göç, 2020: 1528), siyasi ve idari bir kurum olan devlet hukukun üreticisidir. Özellikle modern hukuki kuram, demokratik ve liberal görüşlerin tesiriyle hukuk normlarını oluşturan devlet aygıtının da hukuka bağlı olması gerektiğini ileri sürmektedir (Braud, 2011: 368). Bu da bizleri ilke ve olgu olarak pek çok çalışmanın konusunu teşkil eden hukuk devletine götürmektedir. Toplumsal örgütlenmenin mülk devleti, polis devleti ve onun katı yapısının yumuşatılmış hali olan Hazine Teorisi aşamasından geçildikten sonra eriştiği en çağdaş ve ileri evresi, kuşkusuz hukuk devletidir (Akarsu, 2009'dan aktaran: Yıldız, 2013: 223). Biçimsel ve maddi olarak devletin hukuka bağlı olması şeklinde tanımlanan hukuk devleti kavramı (Özkazanç, 2015:155), vatandaşların devletine karşı güven içerisinde olup, kendi kişiliklerini korkusuzca geliştirmesini sağlayan bir sistemi ifade etmektedir (Özbudun, 2016:126).

Hukuk devleti kavramının kökeni, Kıta Avrupa'sına uzanmaktadır. Ancak Anglo-Sakson hukuk sistemlerinde, kavram olarak "hukukun üstünlüğü" tercih edilmektedir. Hukukun üstünlüğü ve hukuk devleti kavramları arasında içerik olarak farklılıklar olsa da ${ }^{1}$ (Teziç, 2012:163) Tanör ve Yüzbaşığlu (2012: 104-105)'na göre, bunlar arasında ne anlam ne de işlev bakımından önemli bir fark bulunmamaktadır. Hukuk devleti ve hukukun üstünlüğü ile ifade edilmek istenen temel unsur, hukuk kurallarıyla siyasi erkin sınırlandırılmasıdır (Küçük, 2004: 203). Ancak şunu ifade etmek gerekir ki "hukuk devleti" ile "kanun devleti” aynı anlama gelmemektedir. Biçimsel bir görüşe göre bir yönetimin kanunlara dayalı olması, o yönetimi hukuk devleti olarak tanımlamamız için yeterli değildir (Özkazanç, 2015:155). Kanuna uygun olan her sisteme, hukukun üstünlüğüne ve koruyucu üstün ilkelere bağlıdır demek yanlış olur. Bazı durumda yapılan kanunlar baskıcı ve adaletsiz olabilir. Örneğin; mutlak monarşilerde veya diktatörlüklerde kanun olmasına rağmen, bu yönetimlere hukuk devleti denilmemektedir. Bu bağlamda hukukun üstünlüğünün, bağlı olduğu değerler açısından yasanın üstünlüğünden daha koruyucu olduğu söylenebilir (Tanör ve Yüzbaşığlu, 2012:105).

Hukuk devletinin odak noktasını, tüzel kişilik kavramı teşkil etmektedir. Devlet'i, Cumhuriyet'i, Taç'1 ve benzerini, temsil ettiği bireylerden ayırmasını sağlayan bu kavram ile (Braud, 2011:364) iktidarın kişiselleşmesi engellenmek istenmiştir. Devlete hukuki kişilik kazandırılması yoluyla devlet hukuki işlem yapabilir, malvarlığ1 edinebilir, hak ve borç üstlenebilir, mahkeme huzurunda davalı ve davacı olabilir. Ayrıca tüzel kişilik sayesinde devleti yönetenler yaptıkları hukuki işlemleri kendi adına değil, devlet adına yapmış olur (Tunç, 2018: 47) ve devlet adına toplum üzerinde otorite tesis ederlerken, "görünmez bir gerçekliğin görünür yüzü olurlar" (Braud, 2011:364).

Çağdaş demokratik uygarlığın en önemli safhalarından biri olan hukuk devletinde (Özbudun, 2016:126), idareyi bağlayan kuralların mevcudiyeti yeterli değildir. Aynı zamanda yasaların hükümdarın keyfiyetine ve takdirine bağlı olmadan, milli iradeyi temsil eden milletin ya da halkın temsilcileri eliyle konması gerekmektedir. Böylece yönetimin de sınırları belirlenmiş olur. Hukuk herkese eşit bir şekilde uygulanır ve kimseye hukuk nezdinde üstünlük tanınmaz (Yılmaz, 2001: 293-294). Başka bir ifadeyle, faaliyetleri tamamen hukuk tarafindan çerçevelenen ve o şekilde düzenlenen hukuk devleti; devletin farkl1 uzuvlarının ancak hukukun elverdiği ölçüde hareket edebilmesine olanak tanır ve hukukun izin verdiği vasıtaları kullanır (Kaboğlu, 2016: 12-13).

Bir devletin ve devlet idaresinin hukuk devleti olabilmesi için birtakım unsurlara haiz olması gerekmektedir (Gözler ve Kaplan, 2011: 62). Ancak bu unsurlar konusunda farklı görüşler söz konusudur. Örneğin; Gözler ve Kaplan (2011: 62)'a göre hukuk devletinin gerekleri genel gerekler ve özel gerekler şeklinde ikiye ayrılmaktadır. Hukuka bağlılığın göstergesi olan genel gerekler; yasamanın, yürütmenin ve yargının hukuka bağlılığından ibarettir. İdarenin hukuka

${ }^{1}$ Ayrıntılı bilgi için bkz. (Selçuk, 1999). 
bağlılığını ifade eden özel gerekler ise; hâkimlerin bağımsız ve güvenceye kavuşturulmuş olması, hukuki güvenlik, idarenin yargisal denetimi, idarenin mali sorumluluğu ilkelerinin bulunması, idari faaliyetlerin önceden bilinebilir olması ve diğer gerekler şeklinde sıralanmaktadır.

Hukuk devletinin unsurları konusunda genel ve özel gerekler şeklinde bir ayrıma gitmeyen Gözübüyük (2003: 164)'e göre, hukuk devletinin asgari müşterekleri şunlardır; temel haklar güvenliğinin sağlanması (bu güvenceler anayasada belirtilmelidir), yasaların anayasaya uygun olması (yasaların anayasaya uygunluğu yeterli değildir, aynı zamanda anayasaya uygunluğunu sağlayacak bir denetim mekanizmasının sağlanması), yasaların genel olması, yönetimin hukuka bağlı olması, güçler ayrımı ilkesinin uygulanmasi.

Elbette ki sayılan bu unsurların yerleşerek gelişmesi, ülkedeki siyasal özgürlüğü sağlayacak demokratik bir rejimin varlığına bağlıdır. Bu noktada hukuk devletinin demokratik rejimi sınırlayan bir görüş olduğunu belirtmekte yarar vardır. Seçimle işbaşına gelen parlamento, yasaların anayasaya uygunluğunun yargısal denetimi ve katı bir anayasa ile sınırlandırılmaktadır. Hukuk devletinin iktidarı sınırlayan bir mekanizma olarak işlev görmesi, çoğunluğun baskısını önlemek için zorunlu bir koşuldur ve hukuk devleti demokratik rejimin ana ilkelerinden birini teşkil etmektedir (Gözübüyük, 2013: 84).

Kısaca ihtiva ettiği temel hususları bu șekilde sıralanabilen hukuk devletinin iki boyutu bulunmaktadır. Bunlardan ilki, normatif bakımdan hukukun biçim ve usul öğelerini kapsayan hukuk; diğeri adalettir. Hukuk boyutu, bir devletteki herkesin hukuka uymak zorunda olması anlamına gelirken; adalet boyutu ise, kapsam ve amaç bakımından yalnız belirli niteliklere ihtiva eden hukukun üstünlügüüün tanındığ1 toplum düzeni anlamına gelmektedir. Bu tanım da hukukun üstünlüğü ilkesini ön plana çıkarmaktadır (Erkiner, 2013: 354).

Bir ideali ifade eden hukukun üstünlüğü ilkesi, asırlarca süren siyasal iktidarın kısıtlanması ve yönetimde keyfiyetin önlenmesi çabalarının neticesinde gelişen, bireye onurlu ve özgür bir hayat sunan bir tür güvence sistemi olarak ifade edilebilir (Gözlügöl, 2013:1445-1446). İkinci Dünya Savaşı'ndan sonra bu sistemin tesisi anlamında önemli adımlar atılmıştır. İkinci Dünya Savaşı'nın meydana getirdiği büyük tahribat ve ulusal faşist rejimlerin siyasalarla bağlantılı olarak oluşturmuş olduğu şiddet ve y1kımın yenilenmemesi için, dünyada insan hak ve özgürlüklerinin uluslararası alanda da tanınıp, korunması sürecine girilmiştir (Gemalmaz, 2005: 337). Bu bağlamda uluslararası birçok kurum ve kuruluş, hukukun üstünlüğünü sağlama çabası içerisinde olmuştur. Bu minvalde öncelikle küresel olarak Birleşmiş Milletler (BM) (1945), bölgesel olarak ise, Avrupa Konseyi (1949), Avrupa Güvenlik ve İşbirliği Teşkilatı (1975) ve AB ön plana çıkan teşkilatlardır (Gözlügöl, 2013: 1445-1446). Çalışmamızın konusunu teşkil eden AB'nin temel politika ve hedeflerinden birisi de demokrasi, özgürlük, hukukun üstünlüğü ve insan hakları gibi değerleri güvence altına almaktır (T.C. Dışişleri Bakanlığı Avrupa Birliği Başkanlığı, 2019).

\section{Ekonomik Ortaklıktan Siyasi Birliğe Doğru AB}

Tarihsel kökenleri mitolojiye kadar götürülen Avrupa'da birlik oluşturma fikri, öteden beri farklı şekillerde gerçekleşmesi düşünülen bir idealdir. Öyle ki Şarlman, Napolyon ve Hitler gibi pek çok iktidar sahibi, güç kullanarak tek bir Avrupa yaratma arayışı içerisindeyken (Çalış, 2008: 40); Dante La Rochefoucauld, Saint Simon, Victor Hugo, Kant, Due de Sully, William Penn, Augustin Thierry, De Gasperi gibi pek çok düşünür (Karluk, 2014: 1; Çalış, 2008: 40) barışçıl proje ve teklifler ortaya koyarak bu birleşmeyi sağlamaya çalışmışlardır. Ancak bu birleşim idealinin gerçekleşmesi II. Dünya Savaşı'nın meydana getirmiş olduğu büyük tahribatı yaşayan neslin eseri olarak ortaya çıkmıştır (Çalış, 2008: 40). Savaştan hemen sonra Fransa'nın Ekonomik Planlama Komisyonu Başkanı Jean Monnet, devletlerin egemenliklerine müdahale edilmeden, belirli faaliyetleri yürütme konusunda yetkili olabilecek uluslararası kuruluşların kurulması gerektiği anlayışını dile getirmekteydi. Ayrıca bu kuruluşların başarılı olması durumunda, ulusüstü yetkilerle donatılmasını savunmaktaydı. 1945'i izleyen yıllarda Batı Avrupa devletlerinin birçoğu, yaşanan ekonomik ve siyasal sorunların yalnızca ulusal düzeyde çözülemeyeceği görüşündeydi. Bundan dolayı Avrupa'ya özgü teşkil edilecek bölgesel bir kuruluşla, bu sorunların çözülebileceği düşüncesi giderek yaygınlaşmaktaydı. $\mathrm{Bu}$ bağlamda $\mathrm{AB}$ konusunda yeni ve güçlü bir dürtü, 1947 yılında Marshall Planı ve Truman Doktrini ile Amerika Birleşik Devletleri (ABD)'nden geldi. ABD'nin Marshall Planı ile bozulan Avrupa ekonomisini düzeltmek için büyük bir ekonomik yardımda bulunması söz konusu idi. Ancak bu yardımın gerçekleşebilmesi için öncelikle Avrupa devletlerinin kendi aralarında belirli bir program çerçevesinde anlaşmaları gerekiyordu. Bundan dolayı ABD ile sıkı bir işbirliği içerisine giren on altı Batı Avrupa devleti, 1948'in Nisan ayında Avrupa Ekonomik İşbirliği Örgütü (OEEC)'nü kurdu. OEEC, Marshall Planı yardımlarının dağıtımında işbirliği, üyeleri arasında serbest ticaret ortamının sağlanması ve parasal transferlerde çok yönlü kliring sisteminin kurulması konusunda başarılı oldu. Ancak OEEC'nin ulusüstü yetkilerinin yetersiz olduğu anlayışında olan Fransa, Almanya, İtalya, Hollanda, Belçika ve Lüksemburg, Mayıs 1951 tarihinde "Schuman Planı"nı kabul edip, Avrupa Kömür ve Çelik Topluluğu (AKÇT)'nu kurdu (Sander, 2005: 344-345).

Topluluğu kuran Paris Sözleşmesi, 1952 y1lında yürürlüğe girdi. Kurucu altı ülke, kömür ve çelik üretimi ile ilgili politikaları konusundaki yetkilerini oluşturulan üst otorite, AKÇT'ye devretti. Kısa süre içerisinde üye ülkeler, çelik üretiminde iyi bir seviyeye ulaştı. Ekonomik açıdan olumlu gelişmeler kaydeden (Akdemir, 2014: 48) bu altı ülke, sağladığı başarıyı devam ettirebilmek içine ekonomik temelde mal ve hizmetler ile işgücünün serbest dolaşımına dayanan bir topluluğu 1957 yllında kurmaya karar verdi. Kömür, demir, çelik ve hurda ticaretinin yanında diğer alanlarda da ekonomik işbirliğini öngören Roma Anlaşması, 1957 yılında imzalanarak Avrupa Ekonomik Topluluğu (AET) kuruldu. Roma Anlaşması ile Avrupa Atom Enerjisi Topluluğu (EURATOM) da kuruldu (T.C. Dışişleri Bakanlığı Avrupa Birliği Başkanlığı, 2020a). Her ne kadar Roma Anlaşması Avrupa bütünleşmesi açısından oldukça önemli bir hukuki belge (Bilici, 2013: 34) olsa da Birleşik Krallık AET'ye katılmayarak, AET'ye karşılık 
1959 y1lında Avrupa Serbest Ticaret Bölgesi'ni (EFTA) kurdu. Birleşik Krallık, İsveç, Norveç, Danimarka, Avusturya, Portekiz ve İsviçre'nin dâhil olduğu EFTA, AET'ye göre daha esnek bir bütünleşmeyi savunmaktaydı. Kendisini güneş batmayan imparatorluk olarak addeden Birleşik Krallık'ın AET'nin gelişmesini engellemek maksadıyla kurduğu EFTA'nın zaman içinde cılız kalması, Birleşik Krallık'ı topluluğa katılmanın yollarını aramaya $\mathrm{itti}^{2}$ (Sander, 2005: 346).

1965 yllında AKÇT, AET ve EUROTOM Füzyon Antlaşması (Birleşme Anlaşması) ile Avrupa Toplulukları (AT) adı altında birleştirildi. Bu Anlaşma ile tek bir Konsey ve tek bir Komisyon oluşturuldu (T.C. Dişişleri Bakanlığı Avrupa Birliği Başkanlığı, 2020a). 1987 yılında ise, "Tek Avrupa Senedi" belgesi imzalandi. Bu belge ile ortak pazarın gerçekleştirmesi için somut bir adım atılmış olup, bu sürecin 1993 yılında tamamlanması öngörüldü. Ayrıca bu belge ile Avrupa Siyasi İşbirliği Mekanizması'nın AT bünyesine dâhil edilmesiyle Birliğe ilk kez siyasal bir boyut eklendi (Özdemir, 2012: 310). 1992 yılında imzalanıp ertesi yıl yürürlüğe giren "Maastricht Anlaşması" ile topluluk siyasal bir bütünleşmeye doğru evirilmekteydi. Bu Anlaşma ile AT artık yalnızca ekonomik bütünleşme alanı olmayıp, aynı zamanda "ortak dış ve güvenlik politikası" ve "adalet ve içişlerinde işbirliğii" ile siyasi bütünleşmeyi hedefleyen bir birlik oldu. Bununla beraber Maastricht Anlaşması ile oluşan bu yeni yapının ismi "Avrupa Birliği”" olarak değiştirildi (T.C. AB Bakanlığı, AB'ye Genel Bakış, t.y.: 23-24).

22 Haziran 1993 tarihinde gerçekleştirilen Kopenhang Zirvesi'nde Avrupa Konseyi birliğin; adaylık başvurusunda siyasi ve ekonomik kriterler ile topluluk mevzuatının benimsenmesi koşullarını karşılamak üzere Merkezi Doğu Avrupa ülkelerini kapsayacak şekilde genişlemesini kabul etti (T.C. Kamu Denetçiliği Kurumu, 2016).

1997 yılında imzalanan Amsterdam Anlaşması ile ilk kez demokrasi, özgürlük, hukukun üstünlüğü ve insan hakları gibi hususlar, topluluk anlaşmalarında açıkça ifade edildi ve bu hususlar AB'ye üyelik koşullarına eklendi (T.C. AB Bakanlığı, AB'ye Genel Baklş, t.y. : 26-27). 1999 yürürlüğe giren bu anlaşmayla, birliğin ortak karar alma yönteminde değişiklikler yapılarak Parlamento'ya hasredilen yetkiler artırıldı ve Bakanlar Konseyi'nde oybirliği gerektiren hususlar daraltılarak Birliğin uluslararası niteliği geliştirildi (Özdemir, 2012: 310). Amsterdam Antlaşması'ndan sonra, 7-8 Aralık 2000 tarihinde Nice Zirvesi ile temel haklar

\footnotetext{
${ }^{2}$ Altılar'ın başarısı Birleşik Krallık ile birlikte İrlanda ve Danimarka'yı üye olmaya itmiştir. Fransa De Gaulle yönetiminde iki kez $(1963,1967)$ İngiltere'nin üyeliğini reddetse de ilk genişleme dalgasının yaşandığı 1973'te üye olmuşlardır (T.C. Dışişleri Bakanlığı Avrupa Birliği Başkanlığı, 2020a). Akabinde 1981'de Yunanistan 1986'da İspanya ve Portekiz üye olmuştur. Dördüncü genişleme Avusturya, Finlandiya ve İsveç'in üyeliği ile 1995 'te olmuştur. 2004 yılında on ülke ile (Kıbrıs Rum Kesimi, Çek Cumhuriyeti, Estonya, Macaristan, Letonya, Litvanya, Malta, Polonya, Slovakya ve Slovenya) en büyük genişleme yaşanmıştır. 2007'de beșinci genişlemenin devamı olan Romanya ve Bulgaristan'ın üyeliği gerçekleşmiştir. Son olarak 2013'te Hırvatistan birliğe dahil olmuştur (Gürel Günal ve Günal, 2016: 240-241). Ancak 31 Ocak 2020 tarihinde Birleşik Krallık'ın $\mathrm{AB}$ 'den ayrılmasıyla Birliğin üye sayısı 27'ye düşmüştür.
}

açısından AB'nin vatandaşlarına karşı sorumluluklarını içeren Temel Haklar Şartı onaylandı (Bianet, 2001).

\section{Türkiye-AB İliş̧kilerinin Kısa Tarihçesi}

Türkiye AET'ye resmi olarak ilk ortaklık başvurusunu, 31 Temmuz 1959 tarihinde yaptı. Yapılan bu resmi başvurunun ardından AET Bakanlar Konseyi gerekli incelemeleri yaptıktan sonra, Komisyon ile Türkiye arasındaki ilk hazırlık görüşmelerinin 28-30 Eylül 1959 tarihinde yapılmasına karar verdi. Ancak Türkiye'de yaşanan 27 Mayıs 1960 Darbesi ve bunun sonucunda ülke yönetiminin askeri vesayetin elinde olması nedeniyle, topluluk Türkiye ile ikinci adımın atılmasını geciktirdi. 1963 yılında yönetimin sivilleşmesi ile ikinci adımın atılması için gerekli zemin oluştu ve 17 Eylül 1963 tarihinde Türkiye ile AET arasında "Ankara Ortaklık Antlaşması" imzalanarak yeni bir sürece girildi (Akgönenç, 2010: 31-32). TBMM tarafindan 1 Aralık 1964 tarihinde onaylanarak uygulanmaya başlanan Ankara Anlaşması, topluluk müktesebatının bir parçasını teşkil eden uluslararası nitelikli hukuki bir belgedir (Bakkalc1, 2019: 267).

Bu Anlaşma ile Türkiye'nin AET'ye üyelik süreci; hazırlık dönemi, geçiş dönemi ve son dönem olmak üzere üç aşamaya ayrıldı. 1 Aralık 1964 tarihinde başlamış olan hazırlı dönemiyle ilgili kesin bir zaman dilimi belirlenmedi. Türkiye tarafından bu dönemin kısa sürmesine dönük birtakım girişimler başlatılmış olsa da Topluluk bu süreyi uzun tutarak 1970 yılına kadar geçiş dönemine geçilmesine izin vermedi (Bakkalcı, 2019: 269270). 23 Kasım 1970 tarihinde Katma Protokol imzalanarak Türkiye'nin geçiş sürecinin evreleri belirlendi. Türkiye ile Topluluk arasında gümrük birliğinin tamamlanmasına ilişkin şartları ortaya koyan Katma Protokol ile "malların serbest dolaşımı, ortak ticaret ve tarım politikası, gümrükler, rekabet şartları ve devlet yardımları, kamu alımları ve vergilendirme" gibi alanlarda Topluluk mevzuatıyla uyum sağlanmasına ilişkin hususlar ortaya konmuştur (Bilici, 2013: 79). Ancak 12 Eylül 1980'de gerçekleşen askeri darbe ve buna bağlı olarak ülkede yaşanan siyasi ve ekonomik krizden kaynaklı olarak, Topluluk tarafından Türkiye ile olan ilişsiler askıya alınmıştır. Ülkede idarenin sivil hükümete geçmesi, ithal ikameci politikaların hızla terk edilerek dişa açılma sürecine girilmesiyle toplulukla olan ilişkiler tekrar canlanmaya başlamıştır. Öyle ki 14 Nisan 1987 tarihinde Türkiye, Ankara Antlaşması ile belirlenen süreçleri tamamlamadan üyelik başvurusunda bulunmuştur. Ancak 18 Aralık 1989 tarihinde açıklanan karar ile Türkiye'nin topluluğa üyeliği kabul edilmemiştir. Türkiye'nin başvurusuna yaklaşık iki yıl boyunca cevap vermeyen komisyon, yaptığı açıklamada topluluğun yeni bir üyeyi kabul edemeyeceğini ifade etmiştir. Türkiye'nin topluluğa katılmaya ehil olmakla birlikte, sosyo-ekonomik ve siyasal açıdan henüz yeterince gelişmediğini belirtmiştir. $\mathrm{Bu}$ yüzden de tam üyelik müzakerelerinin başlatılması için henüz bir tarih saptanmaması ve Ankara Anlaşması çerçevesinde ilişkilerin geliştirilmesi yönünde önerilerde bulunulmuştur. $\mathrm{Bu}$ öneriler Türkiye tarafından olumlu karşılanarak, Gümrük Birliği'nin Katma Protokol'de öngörülen sürecin tamamlanması için gerekli hazırlıklara başlanmıştır. Nihayet 5 Mart 1995 'te Ortaklık Konseyi toplantısının ardından bütünleşme yönündeki en önemli 
adım atılarak 1 Ocak 1996'da Gümrük Birliği anlaşması yürürlüğe girmiştir. Türkiye-AB ilişkilerinin yeni bir boyut kazandığı bu Anlaşma ile ortaklık ilişkisinin son dönemine geçilmiştir (T.C. Dişişleri Bakanlığı Avrupa Birliği Başkanlığg1, 2020b).

Ardından 1997 yılında gerçekleştirilen Lüksemburg Zirvesi ile Türkiye'nin tam üyeliğe ehil olduğu yinelenmiş; ancak Türkiye genişleme sürecinin dışında tutulmuştur (Bilici: 2013: 81). Türkiye'nin son derece sert bir tutumla eleştirmiş (TBMM Haber Dergisi, 1997-1998:9) olduğu bu kararın ardından 1999 yılında gerçekleşen Helsinki Zirvesi'nde, Türkiye'ye aday ülke statüsü verilmiştir (Bilici: 2013: 81-82). Böylece Birlik mevzuatı gereği aday ülkeler için hazırlanması gereken Katılım Ortaklığı Belgesi $^{3}$, Türkiye için de 2001 yılında düzenlenmiştir. Katılım Ortaklığı Belgesi'nde; katılım hazırlıklarını içeren Ulusal Programın hazırlanması istenmiştir (Bakkalc1, 2019: 314). Türkiye de hazırlamış olduğu Ulusal Programla topluluk müktesebatına uyum sağlamak başta olmak üzere, katılım öncesi stratejilerden yararlanma imkânına kavuşmuştur (Bilici: 2013: 81-82). Nitekim bu süreçte önemli reformları, yasal ve kurumsal düzenlemeleri hayata geçiren Türkiye, 17 Aralık 2004 tarihinde gerçekleştirilen Helsinki Zirvesi ile AB'ye üyelik yolunda önemli bir aşamaya geçmiştir. Söz konusu Zirvede Türkiye'nin siyasi kriterleri yeterli düzeyde sağladığı değerlendirilmesi yapılarak, 3 Ekim 2005 tarihi itibariyle tam üyelik müzakerelerine başlama kararı alınmıştır. Hâlihazırda da Müzakere Çerçeve Belgesi'nde saptanan 35 müktesebat başlığı çerçevesinde tam üyelik müzakerelerine devam edilmektedir (T.C. Dişişleri Bakanlığı Avrupa Birliği Başkanlı̆̆ $1,2020 \mathrm{~b}$ ).

\section{AB'ye Üyelik Sürecinde Türkiye'de Hukukun Üstünlüğüne İlişkin Yapılan Yasal ve Kurumsal Düzenlemeler Üzerine}

AB'nin dayandığı temel değerler açısından hukukun üstünlüğü ilkesine açık bir şekilde yer verilmesine rağmen (Avrupa Birliği Müzakere Sürecinde Yarg1 ve Temel Haklar Fasl1, 2013: 11), birliğin taraf olduğu anlaşma ve mevzuata bakıldığında ilk başlarda bu ilkeye ilişkin herhangi bir tanımlamaya gidilmediği görülmektedir (Magen, 2016: 1051). AB, hukukun üstünlügünü ilkesini demokrasi ve insan haklarına saygı ilkeleri ile ilişkilendirilme yoluna gitmiştir (Pech, 2012: 8). Anayasal demokrasilerin ve çoğulcu toplumların omurgası niteliğinde olan hukukun üstünlüğü ilkesi, Maastricht Anlaşması ile (2. Mad. $\left.{ }^{4}\right)$ özgürlük, demokrasi, eşitlik ve azınlık haklarıyla birlikte birliğin inşasıını oluşturan ilkelerden biri olmuştur. Bundan dolayı birliğe üye olmak isteyen her ülkenin hukukun üstünlüğü ilkesine diğer kurucu ilkelerle beraber uyması şartı getirilmiştir (Soyaltın Colella, 2020: 70).

\footnotetext{
${ }^{3}$ AB'ye aday olan ülkeler için bir yol haritası niteliğinde olan Katılım Ortaklık Belgesi, Türkiye için ilk kez 2001 y1lında AB Komisyonu tarafından hazırlanmıştır (Avrupa Birliği Başkanlığı, 2019).

4"Birlik, insan onuruna sayg1, özgürlük, demokrasi, eşitlik, hukukun üstünlüğü ve azınlıklara mensup kişilerin hakları da dahil olmak üzere insan haklarına saygı değerleri üzerine kuruludur. Bu değerler, çoğulculuk, ayrımcılık yapmama, hoşgörü, adalet, dayanışma ve kadın-erkek eşitliğinin hakim olduğu bir toplumda üye devletler için ortaktır".
}

Nitekim birliğe tam üyelik şartlarının yeniden şekillendirildiği, 21-22 Haziran 1993 tarihli Kopenhag Zirvesi Sonuç Bildirgesi'nde "siyasi kriterler" arasında da hukukun üstünlüğü ilkesine yer verilmiştir (Karluk, 2014: 177). Bu ilkeye önem atfedildiği, yayımlanan Avrupa Komisyon raporlarına bakıldığında daha iyi anlaşılmaktadır. Söz konusu raporlarda, birliğe tam üye olmak isteyen bir devletin hukukun üstünlüğü ilkesi gereği; özellikle kuvvetler ayrılığı, yasama bağ 1 şıklığı, bağımsız mahkemeler vasitasıyla yargısal başvuru olanakları ve yolsuzlukla etkin bir şekilde mücadele edilmesi gibi hususlar bakımından ayrıntılı bir şekilde araştırıldığına vurgu yapılmaktadır (Calliess/Ruffert; Grabitz/Hilf/Nettesheim, Aktaran; Güneş, 2016:327).

31 Temmuz 1959 tarihinde topluluğa üyelik başvurusunda bulunan Türkiye'nin son derece meşakkatli olan üyelik sürecinde kat ettiği en önemli safhalardan biri, hiç kuşkusuz 11-12 Aralık 1999 tarihli Helsinki Zirvesi ile aday ülke statüsünü elde etmesidir. Türk anayasa hukuku ve anayasacılığında $\mathrm{AB}$ faktörünün gittikçe önem kazanmaya başladığı (Tanör ve Yüzbaşığlu, 2012: 65) bu gelişmenin ardından 8 Mart 2001 tarihinde yayımlanan Katılım Ortaklığı Belgesi ${ }^{5}$ ile kısa ve orta vadede birçok yasal ve kurumsal düzenlemeyle mükellef k1lınan Türkiye, hukukun üstünlüğü alanında kapsamlı bir reform sürecine adım atmıştır.

Söz konusu belgede dile getirilen hukuk devletinin gelişimi açısından 2001 yılının sonuna kadar atılması gereken adımlar ya da hedeflerden bazıları şunlardır: Avrupa İnsan Hakları Sözleşmesi (AİHS)'nin 10. maddesi kapsamında ifade özgürlüğünü geliştirmek ve bu durumla ilgili anayasal güçlendirilmenin sağlanması; uluslararası standartlara uygun bir şekilde Devlet Güvenlik Mahkemesi (DGM) de dâhil olmak üzere yargının işlevselliği ve verimliliğini arttırmak, ayrıca yargı mensuplarından hâkim ve savcıların hem insan hakları alanında, hem de AB mevzuatı hakkında eğitimlerin güçlendirilmesi; Avrupa İşkencenin Önlenmesi Sözleşmesi'ne uyulması. Bu Katılım Ortaklığı Belgesi'nde bir y1ldan fazla sürmesi mümkün olan; ancak mümkün mertebe 2001 yılı içerisinde başlatılması öngörülen orta vadeli hedefler kısmında ise, hukuk devleti açısından yer alan bazı maddeler şunlardır; vatandaşların hak ve özgürlükleri ile ilgili anayasa ve diğer ilgili yasaların AİHS çerçevesinde garanti altına alınacak şekilde revize edilmesi; idamın kaldırılması, AİHS 6. Protokolü'nün imzalanıp onaylanması; AB üyesi devletlerin uygulaması göz önünde bulundurularak Milli Güvenlik Kurumu (MGK)'nun hükümete danışma organı olarak uyumu; kültürel çeşitliliğin sağlanması; ceza ve adli konularda $\mathrm{AB}$ müktesebatının benimsenmesi ve uygulanması; din, vicdan ve düşünce özgürlüğü alanında gelişimin sağlanması gibi talepler (Türkiye Katılım Ortaklığı Belgesi, 2001).

Avrupa Komisyonu tarafından hazırlanan Katılım Ortaklığı Belgesi'nden sonra Bakanlar Kurulu'nun 19 Mart 2001 tarihli kararı ile "Avrupa Birliği Müktesebatının Üstlenilmesine İlişkin Türkiye Ulusal Programı" açıklanmıştır. Türkiye'nin 2001 yılı içerisinde siyasi, idari ve yargı alanında reform çalışmalarını hızlandırılacağının

\footnotetext{
${ }^{5}$ Daha sonra bu belge, 19 Mayıs 2003, 23 Ocak 2006 ve 18 Şubat 2008 tarihlerinde revize edilmiştir (https://www.ab.gov.tr/katilimortakligi-belgeleri_46226.html, Erişim Tarihi: 25.02.2020).
} 
belirtildiği Ulusal Program'ın temel amacı, “özgürlükçü, katılımcı, güvenceli, devlet organları arasında görev ve yetkileri dengeleyen, hukuk devleti ilkesini üstün kılan Anayasa ve yasa hükümlerinin, Türkiye'nin uluslararası taahhütleri ile $\mathrm{AB}$ standartları temelinde daha da geliştirilmesi" olarak ifade edilmiştir (2001 Yılı Ulusal Program1, 2001: 17).

Bu kapsamda 3 Ekim 2001 tarihinde 4709 sayll kanun kapsamında Anayasanın başlangıç metni ve bazı maddelerinde $(13,14,19,20,21,22,23,26,28,31,33,34$, $36,38,40,46,49,51,55,65,66,67,69,74,87,89,94$, $100,118,149$, geçici 15 . maddelerinde) değişikliğe gidilmiştir (Altıntaş, 2008: 3). TBMM'de 474 oyla kabul edilen bu paketin yirmi üç maddesi 2001 yılı Ulusal Programı'nda belirtilen unsurlar dikkate alınarak değiştirilmiştir. Dolayısıyla bu değişiklikler işkencenin önlenmesi, düşünce ve ifade özgürlüğü, kişi hürriyeti ve güvenliği, özel hayatın gizliliği, seyahat özgürlüğü, sivil yönetim ve demokrasinin güçlendirilmesi, kadın-erkek eşitliği, iletişim hürriyeti gibi önemli düzenlemeleri içermiştir (T.C. AB Bakanlığı: Siyasi Reformlar-I, t.y.: 8). Ayrıca 1926 yılında kabul edilen Türk Medeni Kanunu, Ülkenin AB ile bütünleşme sürecinde çağın değişen toplumsal ve ekonomik ihtiyaçlara cevap verebilmesi için 2001 yılında çıkarılan 4721 sayılı Yeni Türk Medeni Kanunu'nun kabul edilmesiyle yürürlükten kaldırılmıştır. 1 Ocak 2002 tarihi itibariyle yürürlüğe giren bu kanun, özellikle aile hukuku açısından çocuklar ile korumaya muhtaç toplumsal grupların korunması ve kadın-erkek eşitliği gibi çağdaş düzenlemeleri içermiştir (Altıntaş, 2008: 10).

Türkiye'de daha sonra AB'ye uyum kapsamında 06 Şubat 2002'den 14 Temmuz 2004 tarihine kadar dokuz uyum paketi hazırlanmıştır. 06 Şubat 2002 tarihli 4744 sayılı Bazı Kanunlarda Değişiklik Yapılmasına Dair Kanun'la kabul edilen birinci uyum paketiyle Türk Ceza Kanunu, Devlet Güvenlik Mahkemelerinin Kuruluş ve Yargılama Usulü Hakkında Kanun, Terörle Mücadele Kanunu ve Ceza Muhakemeleri Usulü Kanunu'nda birtakım değişikliklere gidilmiştir. Bu uyum paketinden sonra, 26 Mart 2002 tarihli 4748 Sayılı Kanunlarda Değişiklik Yapılmasına İlişkin Kanun'la ikinci uyum paketi kabul edilmiştir (TBMM, 2004). Söz konusu paketle; Basın Kanunu, Dernekler Kanunu, Devlet Memurları Kanunu, Jandarma Teşkilat, Görev Yetkileri Hakkında Kanun, Devlet Güvenlik Mahkemelerinin Kuruluşu ve Yargılama Usulleri Hakkında Kanun, Siyasi Partiler Kanunu, Toplantı ve Gösteri Yürüyüşleri Kanunu ile İl İdaresi Kanunu'nda değişiklik yapılmıştır (T.C. Başbakanlık Avrupa Birliği Genel Sekreterliği, 2007: 7).

Üçüncü uyum paketi de 03 Ağustos 2002 tarihli 4771 sayılı Çeşitli Kanunlarda Değişiklik Yapılmasına İlişkin Kanun'la kabul edilmiştir. Bu kanun ile ölüm cezası AİHS'nin 6. Protokolüne uygun bir biçimde "savaş, yakın savaş tehlikesi ve terörizm" hariç olmak üzere kaldırılmıştır. Ayrıca farklı dil ve lehçelerde yayın ve öğretim yapma hakkı üzerindeki kısıtlamalar da ortadan kaldırılmış; Hukuk Usulü ve Ceza Yargılaması Usulü Kanunları, Avrupa İnsan Hakları Mahkemesi (AİHM) kararları doğrultusunda ceza ve hukuk davalarında "yargılamanın yenilenmesine" olanak sağlayacak şekilde revize edilmiştir. AB'ye uyum kapsamında yapılan bu düzenlemelere ek olarak
Kaçakçılığın Men ve Takibine Dair Kanun, Orman Kanunu, Dernekler Kanunu, Vakıflar Kanunu, Toplantı ve Gösteri Yürüyüşleri Kanunu, Polis Vazife ve Salahiyetleri Kanunu, Serbest Bölgeler Kanunu'nda değişikliklere gidilmiştir (Altıntaş, 2008: 7). Üçüncü uyum paketi, Avrupa Komisyonu 2002 İlerleme Raporu'nda olumlu bir şekilde karşılık bulmuştur. Rapor'da, üçüncü uyum paketiyle geniş kapsamlı bir reform yapıldı ğ 1 ifade edilmiştir. İlerleme Raporu'nda Türkiye'nin, geçen yıldan beri attığı adımlarla Kopenhang siyasi kriterlerinin karşılanması konusunda gelişim gösterdiği ve yapılan düzenlemelerin ilerde atılacak olan olumlu adımlar için de yol açıcı olduğu belirtilmiştir. Ayrıca Raporda, demokrasinin güçlendirilmesi ve insan haklarının korunması bakımından reform sürecinin teşvik edilmesi gerektiği de ifade edilmiştir (Avrupa Komisyonu, Türkiye Düzenli İlerleme Raporu, 2002: 122-123).

02 Ocak 2003 tarihinde dördüncü uyum paketi, 4778 sayılı Çeşitli Kanunlarda Değişiklik Yapılmasına İlişkin Kanun'la kabul etmiştir. $\mathrm{Bu}$ paketle Ceza Muhakemeleri Usulü Kanunu, Türk Ceza Kanunu, Basın Kanunu, Vakıflar Kanunu, Siyasi Partiler Kanunu, Milletvekili Seçimi Kanunu, Mahalli İdareler ile Mahalle Muhtarları ve İhtiyar Heyetleri Seçimi Kanunu, Dernekler Kanunu, Damga Vergisi Kanunu, İnsan Haklarını İnceleme Komisyonu Kanunu, Dilekçe Hakkının Kullanılmasına Dair Kanun, Adli Sicil Kanunu'nda birçok değişiklik yapılmıştır. Dördüncü uyum paketinin ardından çıkarılan 23 Ocak 2003 tarihli 4793 sayılı Çeşitli Kanunlarda Değişiklik Yapılmasına İlişkin Kanun'la beşinci uyum paketi kabul edilmiştir. Bu uyum paketiyle de Ceza Muhakemeleri Usulü Kanunu, Hukuk Muhakemeleri Usulü Kanunu, Dernekler Kanunu ile ilgili değişiklikler yapılmıştır (TBMM, 2004). Söz konusu uyum paketlerinin çıkartıldı ̆̆1 dönemde AB Konseyi tarafindan 14 Nisan 2003 tarihinde kabul edilen Türkiye için Katılım Ortaklık Belgesi ile başta AİHS 6. Protokolünün onaylanması olmak üzere, tüm bireylerin Türkiye'nin taraf olduğu Avrupa ve uluslararası sözleşmeler doğrultusunda din, inanç, renk, ırk, dil, cinsiyet ve siyasi görüş ayrımı olmaksızın temel hürriyet ve insan haklarından hukuki ve fiili olarak yararlanması; yargı erkinin etkinliğinin ve bağımsızlığının artırılması; DGM'nin işleyişinin AB standartlarına uygun hale getirilmesi ve istinaf mahkemeleri için gerekli hazırlıkların yapılması; hâkim ve savcıların AİHS ve AİHM içtihatları konusunda eğitilmesi; adli suçlar konusunda idari kapasitenin geliştirilmesi, kolluk kuvvetleri arasında işbirliği ve ilgili mevzuat uyumunun sağlanması; MGK'nin işleyişinin $\mathrm{AB}$ üyesi ülkelerde olduğu gibi sivil denetime açık olması şeklinde bir dizi karar alınmıştır (Türkiye Katılım Ortaklığı Belgesi, 2003: 8-9).

Türkiye de Katılım Ortaklığı Belgesi'nde belirtilen reformların uygulanırlığı için 23 Temmuz 2003 tarih ve 2003/5930 Bakanlar Kurulu Kararı ile Avrupa Birliği Müktesebatının Üstlenilmesine İlişkin Türkiye Ulusal Programı'nı revize etme yoluna gitmiştir. 2003 yılında kabul edilen yeni ulusal programa bakıldığında katılım ortaklığı ile ilgili reformlara paralel ifadelere yer verildiği görülmektedir. Ulusal program ile hükümetin bir yasama yılı içerisinde siyasi kriterler açısından yapması gereken yasal düzenlemeler şu şekilde belirtilmiştir: Düşünce ve ifade özgürlüğü alanında başlatılan reformların devam ettirilmesi; dernek kurma özgürlüğü, barışçı toplantı hakkı ve sivil toplum alanında ilerleme, işkence ve kötü 
muamelenin önlenmesi, kamu görevlilerinin insan hakları konusunda eğitimleri; verimli ve işlevsel bir yarg1 sisteminin oluşturulması için insan hakları, AİHM ve AİHS içtihadı konusunda tüm yargı mensuplarını kapsayacak şekilde eğitim programlarının sürdürülmesi; MGK'nın danışma niteliği olan bir kurul olduğunun Anayasa ve ilgili yasa değişiklikleriyle tekrardan belirtilmesi ve MGK ile ona bağlı genel sekreterliğin işlevlerinin buna uygun hale getirilmesi; cezaevleri, tutukevleri ve nezarethane koşullarının Avrupa Konseyi ve Avrupa İşkenceyi Önleme Komitesi'nin tavsiyeleri dikkate alınarak düzenlenmesi, tüm bireylerin, ayrım yapılmaksızın tüm temel hak ve özgürlüklerden tam olarak yararlandırılması ve AİHS ve Ana Hürriyetleri Korumaya Dair Sözleşmeye Ek 13. Protokolü'nün ve BM Uluslararası Medeni ve Siyasi Haklar Sözleşmesi'nin İhtiyari Ek Protokolü'nün imzalanması maksadıyla gereksinim duyulan çalışmaların başlatılması (2003 Y1lı Ulusal Programı, 2003).

2003 y1lı ulusal programından sonra 03 Temmuz 2003 tarihinde de 4928 sayılı Çeşitli Kanunlarda Değişiklik Yapılmasına İlişkin Kanun'la altıncı uyum yasa paketi kabul edilmiştir. Bu paket ile özel televizyonlarda Kürtçe yayın yapabilme imkânı tanınması ile beraber çocuklara bazı isimlerin konması konusunda var olan yasak kaldırılmıştır. Ayrıca bu uyum paketinde DGM ile diğer mahkemeler arasındaki yargılama farklılığı da ortadan kaldırılmıştır. 30 Temmuz 2003 tarihinde de 4963 sayılı Çeşitli Kanunlarda Değişiklik Yapılmasına İlişkin Kanun'la yedinci uyum paketi kabul edilmiştir. Yedinci uyum paketinde MGK'nın görev tanımında değişiklik yapılmış olup, Kurulun yetkilerinde sınırlamaya gidilmiş ve sivillerin de MGK genel sekreteri olabilmesi öngörülmüştür. Aynı zamanda askeri kesimin Sayıştay tarafından denetlenmesine kısmen imkân tanınmıştır. Sivillerin barış döneminde askeri mahkemeler tarafindan yargılanmamasına yönelik düzenlemenin yapıldığı bu pakette, İşkence suçlarının yargılama sürecinde öne alınması ile ilgili düzenleme de yapılmıştır (Karluk ve Tonus, 2004: 11-12). Bu düzenlemelere ek olarak, Toplantı ve Gösteri Yürüyüşleri, Vakıflar Genel Müdürlüğünün Teşkilat ve Görevleri Hakkında KHK, Çocuk Mahkemeleri Kuruluşu, Görev ve Yargılama Usulü Kanunu, Yabancı Dil Eğitimi ve Öğretimi ile Türk Vatandaşlarının Farklı Dil ve Lehçelerinin Öğretilmesi Hakkında Kanunu'nda önemli birtakım değişiklikler yapılmıştır (TBMM, 2004).

Ayrıca bu dönemde hukuk devleti açısından son derece önemli olan, "şeffaf yönetim" ve "yönetimde açıklık" ilkelerine hizmet eden, 9 Eylül 2003 tarih ve 4982 sayılı Bilgi Edinme Hakkı Kanunu çıkarılmıştır. Böylece demokratik ülkelerde vazgeçilmez nitelikte olan bilgi edinme hakkı, Türkiye'nin taraf olduğu uluslararası sözleşmelere ve $\mathrm{AB}$ uyum sürecinde dile getirilen taleplere uygun bir şekilde yasal zemine taşınmıştır (Polater, 2016:100). Bahsi geçen kanunun gerekçesinde bilgi edinme hakkı demokrasinin ve hukukun üstünlüğünün gereği olarak vurgulanmış ve halka yakın bir yönetim, denetim, şeffaflık, kamu güveni gibi faktörler açısından önemine değinilmiştir. Bu hakkın kullanılması ile halkın devleti denetlemesi daha kolay olacağı gibi devletin de demokratik karakterinin güçleneceği ifade edilmiştir (Ceritli, 2012: 37).

07 Mayıs 2004 tarihinde ise, 5170 sayılı Türkiye Cumhuriyeti Anayasasının Bazı Maddelerinin
Değiştirilmesi Hakkında Kanun, TBMM tarafindan kabul edilmiştir. $\mathrm{Bu}$ anayasa değişikliği paketi ile anayasanın 90 . maddesine yürürlüğe konan temel hak ve özgürlüklere ilişkin uluslararası anlaşmalar ile kanunların farklı hükümler içermesi durumunda uluslararası anlaşmaların esas alınacağı yönünde bir cümle eklenmiştir. Böylece uluslararası antlaşmalar ve Avrupa sözleşmeleri iç hukukun üstünde bir nitelik kazanmıştır (5170 sayılı Türkiye Cumhuriyeti Anayasasının Bazı Maddelerinin Değiştirilmesi Hakkında Kanun, md. 7). Söz konusu kanunla aynı zamanda DGM'ler kapatılmış ve ölüm cezasının her koşulda kaldırılması öngörülmüştür (ölüm cezası yerine ağırlaştırılmış müebbet hapis cezası kabul edilmiştir). Anayasa değişiklik paketinde sivil-asker ilişkileri konusunda da düzenleme yapılmıştır. Ayrıca anayasanın Sayıştay'ı düzenleyen 160. maddesinin son fikrasında yer alan "Silahlı Kuvvetler elinde bulunan devlet mallarının TBMM adına denetlenmesi usulleri milli savunma hizmetlerinin gerektirdiği gizlilik esaslarına uygun olarak kanunla düzenlenir" ibaresi, şeffaflık sağlanması açısından yürürlükten kaldırılmıştır (T.C. AB Bakanlığı: Siyasi Reformlar-I, t.y.: 8, 16-17). Kuşkusuz hukuk devleti açısından şeffaflığın yanında yolsuzlukla mücadele etmek de önemli bir durumdur. Bundan dolayı Türkiye, AB'ye uyum kapsamında 01 Ocak 2004 tarihinde "Yolsuzluğa Karş1 Devletler Grubu” (GRECO)'na üye olmuştur (T.C. AB Bakanlığı: Siyasi Reformlar-I, t.y.: 29).

Yapılan bu düzenlemelerden sonra 14 Temmuz 2004 tarihinde TBMM tarafından kabul edilen 5218 sayılı Ölüm Cezasının Kaldırılması ile Bazı Kanunlarda Değişiklik Yapılmasına İlişkin Kanun'la sekizinci uyum paketi kabul edilmiştir. $\mathrm{Bu}$ paketle RTÜK üyeliğine MGK Genel sekreterliğinin aday gösterilmesi ile ilgili hüküm kaldırılmış ve MGK Genel Sekreterinin Haberleşme Yüksek Kurulu üyeliğinden çıkarılması öngörülmüştür. Genel Kurmay Başkanlığı tarafından YÖK'e bir üye seçilmesi uygulamasına son verilmiştir (T.C. Başbakanlık Avrupa Birliği Genel Sekreterliği, 2007: 21). Bu süreçte 26 Eylül 2004 tarihinde Yeni Türk Ceza Kanunu'nun kabulü de Türkiye'nin AB yolunda attığı önemli adımlardan birini teşkil etmektedir. Modern ceza politikasının bir eseri olan Yeni Ceza Kanunu (Altıntaş, 2008: 11) ile suç ve ceza kavramları ve türleri yeniden tanımlanmış, eski kanunda yer almayan eziyet, soykırım, organ ve doku nakli gibi bazı fiiller, suç kapsamına dâhil edilmiştir. Ayrıca Yeni Türk Ceza Kanunu, eski kanundan farklı olarak yalnızca cezalandırma esasına dayanmayıp, aynı zamanda suçlunun sağaltılması ve yeniden cemiyete kazandırılması amacını da gütmektedir (Gözübüyük, 2013: 32).

Yukarıda bahsi geçen yasal düzenlemelerin çıkarıldığı yıl, 6 Ekim 2004 tarihinde yayınlanan Türkiye İlerleme Raporu'nda, Türkiye'de birçok alandaki düzenlemelerin daha fazla genişletilmesi ve yapılan reformların hem yasama, hem de yürütme organlarının tutumlarına yansımasının zaman alacağı ve var olan bürokratik sorunların çözümü için kararlı adımların atılması gerektiği belirtilmiştir (Avrupa Topluluklar Komisyonu, Türkiye Düzenli İlerleme Raporu, 2004:146). Ancak buna rağmen Türkiye'nin özellikle Helsinki Zirvesinden sonra AB üyeliği için gerçekleştirdiği reformların, genel itibarıyla $\mathrm{AB}$ tarafından tasvip edildiğini belirtmekte yarar vardır. Bundan dolayı da 17 Aralık 2004 tarihinde Avrupa Birliği devlet ve hükümet başkanlarının Brüksel'de gerçekleştirmiş 
oldukları zirvede Türkiye ile 03 Ekim 2005 tarihi itibarıyla müzakerelere geçilmesine karar verilmiştir. $\mathrm{Bu}$ karar neticesinde Türkiye'nin AB'ye katılım müzakereleri 03 Ekim 2005 tarihinde Lüksemburg'ta gerçekleştirilen Hükümetler Arası Konferans ile resmen başlamıştır (Baltacı vd., 2012: 143).

Müzakere sürecinin başlaması ile beraber Türkiye'nin üyeliğe hazırlanması çerçevesinde AB Konseyi 23 Ocak 2006 tarihinde Türkiye'ye yönelik Katılım Ortaklığ Belgesini kabul etmiştir. Bu belgede Türkiye'den hukukun üstünlüğü ile ilgili kısa vadede yerine getirmesi istenen bazı reformlar şunlardır: Kamu yönetimi ve personel politikası alanında şeffaflık ve etkinliği sağlayabilmek için reformların sürdürülmesi, Kamu Denetçiliği sisteminin kurulması, Türkiye'de ordu üzerindeki sivil kontrolü uyumlaştırma ve sivil makamların denetim işlevlerinin sürdürülmesi, yolsuzlukla etkin mücadele edilmesi, Kamu Görevlileri Etik Davranış İlkeleri Hakkındaki Yönetmeliğin kapsadığı alanın genişletilerek seçilmiş yetkililer, adli, akademik ve askeri personeli de içerecek biçimde uygulanması. Yasama konusunda parlamenterlerin dokunulmazlıklarının Avrupa uygulamaları kapsamında sinırlandirılması, yarg1 konusunda ise, insan hakları ve temel özgürlükler ile ilgili yasal hükümlerin AİHS ve ilgili içtihadıyla uyumlulaştırılması, Hâkimler ve Savcılar Kurulu (HSYK) ile yeni hâkim ve savcıların atanması konusunda yarg1 bağımsızlığının sağlanması, yarg1 etkinliğinin güçlendirilmesi, AİHS ve AİHM içtihatları konusunda hâkim ve savcilara verilen eğitimlerin devam ettirilmesi (Türkiye Katılım Ortaklığı Belgesi, 2006: 4-6).

Türkiye, AB siyasi kriterlerini karşılamak maksadıyla yukarıda bahsi geçen sekiz uyum paketini hayata geçirdikten sonra, 12 Nisan 2006 tarihinde dokuzuncu uyum paketini kamuoyuna açıklamıştır. Dokuzuncu uyum paketi, Birleşmiş Milletler Yolsuzlukla Mücadele Sözleşmesi, Avrupa İnsan Hakları Sözleşmesinin Oluşturduğu Denetim Mekanizmasının Değiştirilmesine İlişkin 14 No'lu Protokol, Gözden Geçirilmiş Avrupa Sosyal Şartı gibi bazı uluslararası sözleşmelerin onaylanmasıyla birlikte kapsamlı kanun tasarılarını (Kamu Denetçiliği Kanunu, İskan Kanunu, Vakıflar Kanunu, Askeri Mahkemeler Kuruluşu ve Yargılama Usulü Kanununun Bazı Maddelerinde Değişiklik Yapılmasına Dair Kanun) ve birtakım idari tedbirleri (Başbakanlık İnsan Hakları Başkanlığının yeniden yapılandırılması) içermektedir (Avrupa Birliği Müzakere Sürecinde Yargı ve Temel Haklar Fasl1, 2013: 54-55). Dokuzuncu uyum paketinin açıklanmasından sonra, Türkiye'de hukuk devletinin temel şartlarından biri olan, kamuda yolsuzlukla mücadele alanında birtakım çalışmalara başlanmıştır. $\mathrm{Bu}$ kapsamda TBMM tarafindan ilk olarak 18 Mayıs 2006 tarihinde Birleşmiş Milletler Yolsuzlukla Mücadele Sözleşmesi kabul edilmiş, akabinde Meclis tarafindan 15 Haziran 2006 tarihinde de Kamu Denetçiliği Kurumu (Ombudsman) Kanunu kabul etmiştir. Ancak 13 Eylül 2006 tarihinde Resmi Gazete'de yayımlanarak yürürlüğe giren bu kanunun bazı maddelerinin iptali için, dönemin Cumhurbaşkanı Ahmet Necdet Sezer tarafindan Anayasa Mahkemesi'ne başvurulması üzerine, kanunun yürürlüğü durdurulmuştur. Bu düzenlemelerden sonra 13 Ekim 2006 tarihli Resmi Gazetede 2006/32 sayılı "Türkiye'de Saydamlığın Arttırılması ve Kamuda Etkin Yönetimin Geliştirilmesi Komisyonu” başlıklı Başbakanlık Genelgesi ilan edilmiştir. $\mathrm{Bu}$ genelgede yolsuzlukla mücadele konusunda küresel kuruluşlarla koordinasyon sağlanacağı belirtilmiş ve genel prensiplerin belirlenmesi için yapılacak çalışmalarda Komisyona; birlik tarafından sağlanacak kaynaklarla ilgili incelemelerde ise Başbakanlık Teftiş Kurulu Başkanlığı'na destek verilmesi kararlaştırılmıştır (T.C. Başbakanlık Avrupa Birliği Genel Sekreterliği, 2007: 26-27). Kamuda yolsuzluğu önlemek ve şeffaflığı sağlamak için yapılan bu düzenlemeler ile birlikte dokuzuncu uyum paketi kapsamında askeri yargılama ile ilgili TBMM tarafindan 29 Haziran 2006 tarihinde Askeri Mahkemeler Kuruluşu ve Yargılama Usulü Kanununda Değişiklik Yapılmasına Dair Kanun'un kabulü ile askeri yargı alanında birtakım değişikliklere gidilmiştir. Bahsi geçen kanunla siyasi suç niteliğinde olduğu halde askeri suç kapsamına alınan birçok suçta, yapılan düzenleme sonucunda "doğal yargıç ilkesine" dönülmüştür. Ancak yapılan düzenleme sivillerin askeri mahkemelerde yargılanmaması bakımından önemli olsa da tek başına yeterli olmamıştır. Aynı kanunun 12. maddesinde mevcut olan "müşterek suçlar" kavramı değiştirilmediği için, sivillerin bu suçlardan ötürü askeri mahkemelerde yargılanmaları uygulamasına devam edilmiştir (Erdem ve Çoşkun, 2009: 16).

AB üyelik sürecinde hukuk devleti ilkesi bakımından yapılan önemli bir düzenleme de yeni İskan Kanunu'nun kabul edilmesidir. 1934 yılında yürürlüğe giren 2510 sayılı İskan Kanunu fertler arasında ayrımcılık yapması bakımından, hukuk devleti ilkesi ile uyuşmamaktaydı. İlgili kanunda muhacirler ve mültecilerin vatandaşlığa kabulü kısmında Türk kültürüne bağlı olmayanlar, casuslar, anarşistler, memleket dışına çıkarılmış olanlar ve göçebe çingenelerin muhacir olarak alınmayacağı belirtilmişken (Hürriyet, 2004), 19 Eylül 2006 tarihinde kabul edilen 5543 sayılı yeni İskan Kanunu ile "çingeneler" ibaresi metinden çıkarılmış (T.C. Başbakanlık Avrupa Birliği Genel sekreterliği, 2007: 26) ve göç müessesesi ve göçmenlerin Türk vatandaşlığını nasıl elde edecekleri düzenlenmiştir (Öztürk Yılmaz, 2007:262). Bu düzenlemelerin dişında 02 Ekim 2006 tarihinde Türkiye, İnsan Hakları ve Ana Hürriyetlerini Korumaya Dair Sözleşmenin Oluşturduğu Denetim Mekanizmasının Değiştirilmesine İlişkin 14 No'lu Protokole taraf olduğunu belirten belgeyi Avrupa Konseyi'ne iletmiştir (Başbakanlık Avrupa Birliği Genel sekreterliğii, 2007: 26-27).

Kaydedilen bu olumlu gelişmelerin ardından, Avrupa Komisyonu tarafından iki yıl sonra, Türkiye'nin AB üyelik sürecinin sağlıklı yürümesi için Katılım Ortaklığı Belgesi'nde tekrar revizyona gitme yolunu tercih etmiştir. Böylece 18 Şubat 2008 tarihinde yeni Katılım Ortaklığı Belgesi'ni kabul etmiştir. $\mathrm{Bu}$ belgede Türkiye'den demokrasi ve hukukun üstünlüğü ile ilgili kısa vadede yerine getirmesi istenen hususların bazıları şunlardır: kamu yönetimi alanında, Kamu Denetçiliği sistemini kurmayı amaçlayan mevzuatın uygulanması, yerel yönetimin güçlendirilmesi, etkinliğin genişletilmesi, şeffaflık ve mali sorumluluğun sağlanması amacıyla personel politikaları ve kamu yönetimindeki reformların takibi; güvenlik güçlerinin sivil denetimini sağlayabilmek için, sivil denetimde $\mathrm{AB}$ üyesi ülkelerdeki uygulamalarla uyum sağlanması yönünde yapılan reformların sürdürülmesi. Sivillerin güvenlik güçlerini denetlemesi konusunda ise, askeri mahkemelerin yalnızca askeri personelin askeri vazifeleri konusuyla 
sınırlandırılması; savunma ve askeri politikalarla ilgili dış denetim de dâhil olmak şartıyla yapılacak bütün harcamalar için parlamenter gözetimin tesis edilmesi. Yargı sistemi için ise, temel haklar ve insan hakları dahil tüm yasal hükümlerin yargı mercileri tarafindan AİHM içtihatları, Avrupa İnsan Haklarının ve Temel Özgürlüklerin Korunması Sözleşmesi ve Anayasanın 90. maddesi çerçevesinde yorumlanmasının sağlanması yolundaki gayretin artırılması; yargının tamamının HSYK tarafindan temsilinin sağlanması, yargının işlevselliğinin artırılması, Bölge Adliye Mahkemelerinin tesisi. Yolsuzlukla mücadele konusunda ise, kapsamlı bir stratejinin benimsenmesi, Kamu Görevlileri Etik Davranış İlkeleri Hakkındaki Yönetmeliğin askeri, adli, akademik olmak üzere hâkimiyetinin genişletilerek etkin bir şekilde uygulanması, milletvekillerine ve kamu çalışanlarına uygulanan dokunulmazlık kapsamının Avrupa uygulamaları doğrultusunda kısitlanması. Siyasi partilerin ve seçim kampanyalarının finansmanı hususunda şeffaflığa ilişkin mevzuatın iyileştirilmesi (Türkiye Katılım Ortaklı̆̆ 1 Belgesi, 2008: 5-6). Katılım Ortaklığ belgesinde belirtilen reform taleplerini gerçekleştirmek için Türkiye'de 10 Kasım 2008 tarihli Bakanlar Kurulu Kararı ile "Avrupa Birliği Müktesebatının Üstlenilmesine İlişkin Türkiye Ulusal Programı" kabul edilmiştir. Türkiye'nin Kopenhag kriterlerini başarılı bir şekilde benimsediğinin belirtildiği ulusal programda, siyasi kriterler kısmında demokrasi ve hukukun üstünlüğü, insan hakları, temel hak ve özgürlükler konusunda yapılan reformların uygulama konusundaki etkinliğinin arttırılarak sürdürülmesi ve ihtiyaç duyulan tamamlayıcı düzenlemelerin de erken bir zamanda hayata geçirilmesi hususunda hükümetin iradesinin tam olduğu belirtilmiştir (2008 Yılı Ulusal Programı, 2008:4-5).

Bu irade beyanından sonra $A B$ 'ye üyelik için atılan önemli diğer bir adım da 12 Eylül 2010 tarihinde gerçekleştirilen referandum sonucunda 5982 sayılı Anayasa Değişiklik Paketinin kabul edilmesidir. Bu pakette idarenin işleyişiyle ilgili şikâyetleri incelemek maksadıyla Kamu Denetçiliği Kurumu'nun teşkili öngörülmüştür (Yücel, 2012: 91). Anayasada yer alan dilekçe hakkına ilişkin madde, "dilekçe, bilgi edinme ve kamu denetçisine başvurma hakkı" olarak değiştirilmiş ve metne “...herkes, bilgi edinme ve Kamu Denetçisine başvurma hakkına sahiptir. Türkiye Büyük Millet Meclisi Başkanlığı'na bağlı olarak kurulan Kamu Denetçiliği Kurumu, idarenin işleyişiyle ilgili şikâyetleri inceler. Kamu Başdenetçisi Türkiye Büyük Millet Meclisi tarafından gizli oyla dört yıl için seçilir...." ibareleri eklenmiştir. Yapılan bu değişiklik ile kamu denetçiliği, anayasal nitelikte bir kurum olmuş ve gerekli yasal düzenlemeler yapıldıktan sonra kurumun işler hale getirilmesi amaçlanmıştır (Kahraman, 2011: 368-369). Bu amaç doğrultusunda 14 Haziran 2012 tarih ve 6328 sayılı kanunla Kamu Denetçiliği Kurumu oluşturulmuştur.

2010 Anayasa reformu paketiyle Anayasanın 145. maddesinde yapılan değişikliklerle askeri yargının görev alanı, askeri suçların yargılanmasıyla kısıtlanmış; devlet güvenliği ve anayasal düzene karşı işlenen suçların adliye mahkemelerinde görüleceği düzenlenmiş; asker olmayan kişilerin, askeri mahkemelerde savaş hali dışında yargılanamayacağı anayasal güvenceye kavuşturulmuştur (Avrupa Birliği Müzakere Sürecinde Yarg1 ve Temel Haklar Fasl, 2013: 52-53). Ayrıca bu değişiklik paketi ile yeni bir HSYK yapısı da oluşturulmuştur. Uluslararası kriterlere uyum sağlanması amaçlanan yeni HSYK yapısında Adalet Bakanı ve Müsteşarı'nın kuruldaki konumlarında kısmen de olsa bir zayıflama olmuştur. Her ne kadar kurulun başında Adalet Bakanının bulunmasına devam edilse de HSYK'da oluşturulan üç dairenin çalışmalarına Adalet Bakanının katılmamasına ve Bakanın yalnızca genel kurula katılarak oy kullanmasina karar verilmiştir. Disiplin ve özlük işleri ile ilgili kararların dairelerde alınması ve bu dairelerin çalışmalarına Bakanın katılamamasından dolayı bu tarz konularda oy hakkına sahip olmamasını, yargı erkinin tarafsızlığı ve bağımsızlığı açısından önemli bir husus olarak değerlendirmek mümkündür. HSYK'nın doğal üyesi olan Adalet Bakanı Müsteşarı ise, dairelerden birinin çalışmasında bulunarak oy kullanma hakkına sahiptir. Ancak kurulun ve dairelerin toplanarak çalışabilmeleri için Müsteşarın toplantıya iştiraki zorunluluğunun kaldırılmış olması da önemli bir yeniliktir. Yapılan diğer bir yenilik ise, HSYK'nın üye sayısında değiş̧ikliğe gidilmesidir. $\mathrm{Bu}$ değişiklikten önce Adalet Bakanı, Müsteşarı, Yargıtay ve Danıştay üyeleri arasından seçilen beş üye ile birlikte toplam yedi üyeden oluşmaktaydı. Değişiklik ile HSYK'nın 22 asıl ve on iki yedek üyeden oluşturulması öngörülmüştür. Böylece kurul karma bir yapı haline gelmiştir. Bundan dolayı kurulda birçok farklı görüşün katkı sağlayacağı düşünülmektedir. HSYK ile ilgili diğer bir düzenleme de hâkim ve savcıların denetiminin geçmiş dönemlerde bakanlığın müfettişleri tarafından yapılmakta iken, değişiklikle birlikte bu işlemlerim HSYK başkanının onayıyla kurul müfettişlerince gerçekleştirilmesine karar verilmesidir (Özkul, 2016: 248-252). Yargının bağımsızlığını sağlamak için HSYK yapısında gerçekleştirilen bu düzenleme ile birlikte Anayasa Mahkemesi'nin oluşumu, üye seçimi ve çalışma şeklinde değişikliğe gidilmiş ve Anayasa Mahkemesi'ne bireysel başvuru hakkı getirilmiştir. Yapılan bu değişikliklerle 1982 Anayasası, AB normlarına daha uyumlu hale gelmiştir. Yarg1 konusunda Avrupa standartlarını yakalamak isteyen Türkiye, 2011 yılından 2014 yılına kadar beş yargı reformu paketini ${ }^{6}$ kabul ederek, yargı sisteminde insan hakları ihlallerinin önüne geçmeyi ve adil yargılama hakkı ile ilgili iyileştirmeler yapmayı amaçlamıştır (Avrupa Birliği Müzakere Sürecinde Yargı ve Temel Haklar Fasl, t.y.: 52-53, 55).

$\mathrm{Bu}$ süreçte yargı etkinliği ile ilgili yapılan önemli gelişmelerinden birisi de 07 Haziran 2012 tarihinde kabul edilen Hukuk Uyuşmazlıklarında Arabuluculuk Kanunu'dur. $\mathrm{Bu}$ kanunla mahkemelerin ağır işyükünün hafifletilmesi ve uzun yargılama süreçlerinin işleyen bir

\footnotetext{
${ }^{6}$ Birinci reform 31.03.2011 tarihinde kabul edilen 6217 say1l "Yargı Hizmetlerinin Hızlandırılması Amaciyla Bazı Kanunlarda Değişiklik Yapılmasına Dair Kanun”; ikinci reform 650 sayılı Kanun Hükmünde Kararname; üçüncü reform 02.07.2012 tarihinde kabul edilen 6352 sayılı "Yarg1 Hizmetlerinin Etkinleştirilmesi Amacıyla Bazı Kanunlarda Değişiklik Yapılması ve Basın Yayın Yoluyla İşlenen Suçlara İlişkin Dava ve Cezaların Ertelenmesi Hakkında Kanun"; dördüncü reform paketi 11.04.2013 tarihinde kabul edilen 6459 sayılı "Insan Hakları ve İfade Özgürlüğü Bağlamında Bazı Kanunlarda Değiş̧iklik Yapılmasına Dair Kanun"; beşinci paket ise, 21.02.2014 tarihinde kabul edilen 6526 sayılı "Terörle Mücadele Kanunu ve Ceza Muhakemesi Kanunu ile Bazı Kanunlarda Değişiklik Yapılmasına Dair Kanun"dur (Avrupa Birliği Müzakere Sürecinde Yarg1 ve Temel Haklar Fasl1,t.y.: 55).
} 
arabuluculuk mekanizmasının devreye konularak yeniden düzenlenmesi hedeflenmiştir (Akgül Açıkmeşe ve Hisarlığlu, 2017:180). Türkiye'nin göstermiş olduğu bu performanstan son derece etkilenen Avrupa Komisyonu'na göre, Türkiye 2007 ve 2013 yılları arasında yargı konusunda oldukça önemli adımlar atmıştır. Ancak bu dönemde kaydedilen ilerleme, 2014 yılının başından itibaren durma noktasına gelmiştir. 2014 yılından sonraki süreçte erkler ayrılığı ve yargının bağımsızlığı ilkesinin zayıfladığg, hâkim ve savcılara dönük siyasi baskıların arttığı yönündeki eleştiriler artmıştır (Avrupa Komisyonu, Türkiye 2015 Y1lı İlerleme Raporu, 2015: 14).

Her ne kadar 2014 yılında partilerin ve adayların seçim propagandalarında farklı dil ve lehçelerin kullanılmasına olanak tanınması, eş genel başkanlığa izin verilmesi, siyasi partilere ilçe örgütlenmesi konusunda kolaylı̆̆ın sağlanması, genel seçimlerde hazine yardımının geçerli oyların \%3'ünden fazlasını alanlara da verilmesi, farklı dil ve lehçelerde eğitim veren özel okulların açılabilmesine olanak tanınması (Özdemir ve Çiftçi, 2015: 139) gibi gelişmeler yaşansa da Gezi eylemleriyle birlikte $A B$ tarafından Türkiye'ye yöneltilen eleştirilerin arttığı görülmektedir.

27 Mayıs 2013 günü, İstanbul'da Gezi eylemleri sürecinde biri polis memuru altı kişi hayatını kaybetmiş ve yaklaşık sekiz binden fazla eylemci yaralanmıştır (Avrupa Komisyonu, Türkiye 2013 İlerleme Raporu, 2013: 5-6; Ergun, 2014:509). Gezi eylemleri ve bu eylemler sirasinda protestoculara polisin müdahalede bulunması, $\mathrm{AB}$ tarafindan toplum özgürlüğüne saygı çerçevesinde değerlendirilmiş ve siyasi kriterler başlığında eleştirilmiştir (Avrupa Komisyonu, Türkiye 2013 İlerleme Raporu, 2013: 65). Yaşanan bu süreçle ilgili $A B$ komisyonu yazılı açıklamada bulunarak "Her türlü aşırı ve orantısız kuvvet kullanımını kınadığını” açıklamıştır (Milliyet, 2013). 2013 yılında yaşanan diğer bir olay 17-25 Aralık operasyonudur. 2014 ilerleme raporunda; hem yolsuzluk iddiası hem de devlet içindeki paralel yapının yargı içinde gerçekleştirmeye çalıştı̆̆ı darbe iddiasına yer verilmiştir. Yolsuzluk iddiasına konu olan dört bakan için hazırlanan dokunulmazlıkların kaldırılmasına dair fezlekelerin gecikmiş olması, AB tarafindan eleştirilmiş, yargı bağımsızlığı konusunda endişeler olduğu dile getirilmiştir ve konunun araştırılması gerektiği üzerinde durulmuştur (Avrupa Komisyonu, Türkiye 2014 İlerleme Raporu, 2014: 9-10). Ülkede yaşanan bu süreçlerden sonra 17 Nisan 2014 tarihinde 6532 sayılı Devlet İstihbarat Hizmetleri ve Millî İstihbarat Teşkilatı Kanununda Değişiklik Yapılmasına Dair Kanun kabul edilmiştir. Milli İstihbarat Teşkilatı ile ilgili yapılan bu düzenleme, AB tarafindan 2014 ilerleme raporunda eleştirilmiştir. MIT'in özellikle denetim yetkisinin artırılması, MIT personelinin dokunulmazlığının kapsamının genişletilmesi ve güvenlik sektöründeki mali saydamlığın kısıtlanması AB'yi rahatsız etmiştir (Avrupa Komisyonu, Türkiye 2014 İlerleme Raporu, 2014: 11)

2015 yllında iki genel seçim gerçekleştirilmiştir. 7 Haziran'da gerçekleştirilen ilk seçimde hiçbir parti, hükümeti kuracak çoğunluğu elde edememiş ve yapılan koalisyon görüşmelerinden de sonuç alınamayınca erken seçime gitme kararı alınmıştır. Alınan karar sonucunda 1 Kasım 2015 tarihinde Türkiye ikinci kez sandığa gitmiş ve
Adalet ve Kalkınma Partisi bu kez tek başına iktidara gelmiştir. Ancak aradan sekiz ay geçtikten sonra, Ülke 15 Temmuz 2016 tarihinde darbe girişimi ile karşılaşmıştır. Bu girişimde 251 vatandaş hayatını kaybetmiş, 2194 vatandaş yaralanmıştır. Darbe girişiminden altı gün sonra ülkede Olağanüstü Hal (OHAL) ilan edilmiş olup, OHAL 18 Temmuz 2018 tarihine kadar sürmüştür. İki yıllık OHAL süresince 36 Kanun Hükmünde Kararname (KHK) yayınlanmıştır (Euronews, 2019). OHAL döneminde çıkartılan KHK'ların bazıları olağanüstü halin gerekleri ile ilgili olmayan düzenlemeleri içerdiği gerekçesiyle eleştirilmiştir. 674 sayılı KHK ile üniversitelerdeki araştırma görevlileri ile ilgili yapılan düzenleme (ÖYP kadrosunun 50/d kadrosuna nakledilmesi), 676 sayılı KHK ile rektörlük seçimi ile ilgili yapılan düzenleme, $687 \mathrm{KHK}$ ile kış lastiği zorunluluğunun getirilmesi gibi hususlar bu kapsama girmektedir (Günday, 2017: 31-32).

Diğer taraftan Akça vd., 15 Temmuz darbe girişiminin ardından çıkarılan ve mevcut mevzuatta değişiklik yapan KHK'ların bir kısmının geçici nitelikte değil, aksine olağanüstü hal için öngörülen süreyi aşan kalıcı nitelikli düzenlemeler olduğunu belirtmiştir. Kuvvet Komutanlıklarının MSB'ye bağlanması, Ceza Muhakemesi Kanunu ile ceza muhakeme usulünün kalıcı biçimde değiştirilmesi, Telekomünikasyon İletişim Başkanlığı'nın kaldırılması ve yetkilerinin Bilgi Teknolojileri ve İletişim Kurumu'na devredilmesi, Varlık Fonu ve Türkiye Maarif Vakfi'nın yetkilerinin genişletilmesi, yüksek yargının yeniden yapılandırılması, MIT'in Cumhurbaşkanlığına bağlanması gibi tümüyle kalıcı nitelikteki düzenlemeler bu kapsamda sayılabilir. Olağan dönemde de geçerlilik arz edecek, kurumların işleyişini köklü değişikliğe uğratan bu kapsamlı düzenlemelerin, yasama organı olan mecliste tartışılmaksızın ve sadece olağanüstü halden dolayı kısıtlı şekilde başvurulabilecek bir usulle yapılması, yasama yetkisinin dokunulmazlığına, güçler ayrılığına ve hukuki güvenlik prensibine açıkça aykırı görülmüştür (Akça vd., 2018:103). Sonuç olarak çıkartılan KHK'ların çok azı Mecliste görüşülüp kabul edilmiştir. KHK'ların büyük bir kısmı ise, Meclis ve Anayasa Mahkemesi denetiminden geçmeden uygulanmıştır (Akça vd., 2018:99). AİHM eski yargıçlarından Rıza Türmen'e göre bu durum hukuk devletini zedelemiştir (Kurnaz, 2020).

Ayrıca 15 Temmuz'da yaşanan darbe girişiminin bastırılmasına destek veren siviller için 08 Kasım 2016 tarihinde kabul edilen 6755 sayılı Olağanüstü Hal Kapsamında Alınması Gereken Tedbirler ile Bazı Kurum ve Kuruluşlara Dair Düzenleme Yapılması Hakkında Kanun Hükmünde Kararnamenin Değiştirilerek Kabul Edilmesine Dair Kanun'la darbe teşebbüsü, terör eylemleri ve bunların devamı sayllacak eylemlerin önlenmesi noktasında karar alanlar, bunları uygulayanlar, olağanüstü hal boyunca ortaya çıkan KHK'lar kapsamında görevlerini icra edenler hakkında idari, mali, hukuki ve cezai sorumluluğun doğmayacağı hüküm altına alınıştır (6755 sayılı Kanun, md. 37). 24 Aralık 2017 tarihinde çıkartılan 696 sayılı KHK ile de resmi bir sıfatı olup olmadığına ya da resmi bir görevi yerine getirip getirmediğine bakılmaksızın darbenin bastırılmasında hareket edenler hakkında da aynı madde hükümlerinin uygulanması kararlaştırılmıştır. $\mathrm{Bu}$ değişiklik ile hukuka uygunluk sebeplerinin (zorunluluk ve meşru müdafaa) dışında sivil kişilere bir ceza muafiyeti getirilmiştir. Yapılan bu düzenlemenin hem Türkiye'nin 
taraf olduğu uluslararası sözleşmelerle, hem de hukuk devleti ilkesiyle bağdaşmadığına ilişkin literatürde geniş bir tartışmaya yer verilmektedir (Akça vd., 2018.: 66-67).

Bu süreçte ortaya çıkan istikrarsız tablo, Türkiye gündemini zaman zaman meşgul eden başkanlık sistemi tartışmalarını gündeme getirmiştir. Hükümet istikrarsızlığını ortadan kaldırmak ve hantal olarak nitelendirilen karar alma sürecine etkinlik kazandırmak savlarıyla temellendirilen Cumhurbaşkanlığı Hükümet Sistemi'ne geçiş yaşanmıştır (Gönenç, 2018:2). Yeni sistemde Cumhurbaşkanı kendisine tanınan geniş yetkilerle hem yargı, hem de yasama karşısında güçlenerek yürütmenin tek sahibi konumuna gelmiştir (Esen, 2016: 71). Cumhurbaşkanlığ1 Hükümet Sistemi'ne geçiş, OHAL döneminde 6771 sayılı Türkiye Cumhuriyeti Anayasasında Değişiklik Yapılmasına Dair Kanun'un, başka bir ifadeyle Cumhurbaşkanlığı Hükümet Sistemi'ni getiren Anayasa değişikliklerinin oylanması maksadıyla 16 Nisan 2017'de yapılan referandum ile olmuştur. Bahsi geçen referandumda icra edilen kampanyanın her iki taraf için eşit şartlarda gerçekleşmediğini ifade eden $\mathrm{AB}$ komisyonu, OHAL'in yarattığı genel olumsuz atmosferde yapılan bu referandumun uluslararası gözlemlerde ciddi endişelere yol açtığını ve seçimin dürüstlüğüne dönük genel ilke ve önlemlere gölge düşürüldüğünü dile getirmiştir (Avrupa Komisyonu, Türkiye Raporu, 2018: 10).

$\mathrm{Bu}$ referandum kadar, 24 Haziran 2018 tarihinde gerçekleştirilen Cumhurbaşkanı ve milletvekili seçiminin de uluslararası gözlemciler tarafindan endişe ile karşılandığ 1 belirtilmiştir. En son yayınlanan ilerleme raporunda seçimlerin yanı sıra, yeni hükümet sistemine ilişkin ciddi eleştiriler getirilmiştir. Şöyle ki Cumhurbaşkanlığı Hükümet Sistemi'nin Meclisin yasama ve denetim işlevlerini kayda değer düzeyde kısıtladığı, daha önce mevcut olan birçok denge ve denetleme mekanizmasına son verdiği, kamu yönetiminin ve yargının daha fazla politikleşmesine sebebiyet verdiği ve Cumhurbaşkanı'na birçok düzenleyici kamu kurumunun başkanını atama yetkisi verdiği yönünde eleştiriler burada sıralanabilir. Ayrıca 15 Temmuz darbe girişiminin ardından ülkede insan hakları, hukukun üstünlüğü ve yargının bağımsızlığına ilişkin kötüleşen durumun rapor döneminde sürdüğü ifade edilmiştir. Başbakanlık makamı ile bakanlıklardaki müsteşarlık makamı gibi birimlerin lağvedilmesini de kapsayan yeni hükümet sisteminin, kamu yönetiminin daha fazla politikleşmesine yol açtı̆̆ 1 ifade edilmiştir (Avrupa Komisyonu, Türkiye Raporu, 2019: 1015).

\section{Sonuc}

Hukukun üstünlüğü ilkesi, AB açısından birlik oluşturma aşamasında önemli bir adım olan Maastricht Anlaşması ile öne sürdüğü koşullardan birisidir. Üye olmak isteyen devletler kurucu ilkelerle birlikte hukukun üstünlüğünü garanti etmelidir. Bu bağlamda AB'ye üyelik süreci insan hakları temelinde zorlayıcı birtakım reformların yapılmasını gerekli kılmaktadır. Öteden beri AB'ye üye olmak isteyen Türkiye'nin aday ülke statüsünü elde ettiği Helsinki Zirvesi ile hukukun üstünlüğü ve insan hakları konusunda yeni bir döneme geçtiği görülmüştür. 2001 yılında imzalanan Katılım Ortaklık Belgesi'nde kısa ve orta vadede atılması gereken adımlar belirlenmiştir.
Aynı tarihte harekete geçen Türkiye siyasi, idari ve yargı alanlarında birtakım reformlar gerçekleştirmiştir. Anayasanın bazı maddeleri; işkencenin önlenmesi, düşünce özgürlüğü, kişi hürriyeti, özel hayatın gizliliği, sivil yönetim ve demokrasinin güçlenmesi, iletişim hürriyeti gibi noktaları gözeterek değiştirilmiştir. Akabinde 2002-2004 yılları arasında hazırlanan uyum paketleri aracılığı ile yarg1, kamu personeli, siyasi partiler ve askeri alanlarda yeni düzenlemeler yapılmış ve ölüm cezasının kaldırılması, toplumsal farklılıkların görünür kılınması, sivil siyaset üzerindeki askeri vesayetin kaldırılması, toplumdaki örgütlenme düzeyinin önünün açılması şeklinde temel hürriyet ve haklara taalluk eden reformlar gerçekleştirilmiştir. Bu reformlar yalnızca yasal düzeyde kalmamıştır. Reformların çeşitli eğitimlerle yerleşmesi ve bir kültüre dönüşmesi amacıyla kamu görevlileri ile yarg1 mensuplarının eğitilmesi noktasında kararlar alınmıştır. Yönetsel açıdan şeffaflık ilke olarak benimsenmiş ve vatandaşların bilgi edinme haklarını etkin kullanabilmeleri adına çeşitli düzenlemeler yapılmıştır.

Yaşanan gelişmeleri önemli gören AB, 2004 yılının son ayında Türkiye ile müzakere sürecini başlatma kararı almıştır. Yönetsel anlamda şeffaflığın yanı sıra, yolsuzlukla mücadele, etkinlik, kamuda etik gibi konularda düzenleme yapılması ve kamu denetçiliği aracılığıyla yönetsel alanın hesap verebilirlik açısından denetlenmesi öngörülmüştür. Yarg1 alanında yargı bağımsızlığının tam olarak sağlanması ve eğitimlerin devam ettirilmesi şeklinde kararlar alınmıştır. 2010 yılına kadar birçok adım atılmış ve bu yılda yapılan Anayasa değişikliği ile Kamu Denetçiliği Kurumu'nun kurulması sağlanmıştır. Asker olmayanların askeri mahkemede yargılanmamaları güvence altına alınmış, Anayasa Mahkemesi'ne bireysel başvuru hakkı ve arabuluculuk getirilmiştir.

Tüm gelişmelere rağmen 2013 yılında yaşanan Gezi eylemlerinde eylemcilere yapılan müdahalelerin boyutu ve 2014 y1lında meydana gelen ve kamuoyuna "yolsuzluk" olarak yansıyan operasyonların sonunda bakanların dokunulmazlıklarının kaldırılmasının gecikmesi ilerleme raporlarında eleştirilmiştir. Aynı yıl MíT'e tanınan yetkilerin artırılması, 2016 yılında meydana gelen darbe girişimi nedeniyle başlayan OHAL ve akabinde üst üste çıkan KHK'ların, hukuk devleti ilkesini zedelediği yönünde bir anlayış oluşturmuştur. Son olarak 2018 yılında geçiş yapılan Cumhurbaşkanlığı Hükümet Sistemi'nin yasamanın alanını daralttığı, yargının siyasallaşmasına ve kamu yönetiminin politikleşmesine yol açtığ anlamda sürecin başında olumlu yaklaşımların yer aldığ raporlarda eleştirilerin arttığı görülmüştür.

Genel olarak değerlendirildiğinde, Türkiye AB'ye resmi adaylık statüsü elde ettikten kısa bir süre sonra önüne konulan müktesebata uygun adımları ilk yıllarda kararlı bir şekilde atmıştır. Bu da elbette ki, ülkede hukukun üstünlüğü ve insan hakları alanında ciddi ivme kazanılmasını sağlamıştır. Ancak 2014 yılından sonra ülke içinde gelişen toplumsal muhalefet, darbe girişimi ve akabinde yaşanan birtakım olumsuz gelişmeler neticesinde $\mathrm{AB}$ müktesebatına uyum sağlamak öncelik olmaktan çıkmış, bunun yerine siyasi istikrarı sağlamak adına, kriz dönemlerini yönetmekte daha etkili olduğu düşünülen hükümet sistemi değişikliğine gidilmiştir. $\mathrm{Bu}$ değişiklik de $\mathrm{AB}$ tarafından eleştiri ile karşılanmıştır. 


\section{Kaynakça}

Akça, İ., Algül, S., Dinçer, H., Keleşoğlu, E., \& Özden, B. A. (2018). Olağanlaşan OHAL: KHK'ların Yasal Mevzuat Üzerindeki Etkileri. (Erişim: 20.02.2020), https://tr.boell.org/sites/default/files/ohal_rapor_web .pdf.

Akdemir, E. (2014). Avrupa Bütünleşmesinin Tarihçesi. İçinde: Belgin Akçay \& İlke Göçmen (Ed.), Avrupa Birliği Tarihçe, Teoriler, Kurumlar ve Politikalar (s. 39-66). Ankara: Seçkin Yayıncılık.

Akgönenç, O. (2010). Türkiye’nin AB Stratejisi. Ankara: Nobel Yayın.

Akgül Açıkmeşe, S. \&Hisarlığlu, F. (2017). Avrupa Koşulluğu ve Türkiye'de Siyasi Reform Süreci. İçinde: Belgin Akçay \& Sinem Akgül Açıkmeşe, Yarım Asrın Ardından Türkiye- Avrupa Birliği İlişkileri (s. 167-196). Ankara: Seçkin Yayıncılık.

Altıntaş, Ö. F. (2008). Avrupa Birliği’ne Aday Ülke Olarak Türkiye'de AB Uyum Yasalarının İc Hukuka Etki ve Katklsi. (Erişim Tarihi: 15.02.2020), http://www.abgm.adalet.gov.tr/yayinlar/belgeler/eku tuphane/ABUyumYasalarininIcHukukaEtkisiVeKat kisi.pdf.

Atmaca, Y. \& Göç, E. (2020). Türkiye'de 1960 ve 1980 Kurucu Meclisleri: Demokratik Nitelikleri Bağlamında Karşılaştırmalı Bir Değerlendirme. OPUS-Uluslararası Toplum Araştırmaları Dergisi, 16(28), 1524-1540.

Avrupa Birliği Başkanlığı (2019). Katılım Ortaklık Belgeleri. (Erişim Tarihi: 01.02.2020), https://www.ab.gov.tr/katilim-ortakligibelgeleri_46226.html.

Avrupa Birliği Müzakere Sürecinde Yargı ve Temel Haklar Faslı (2013). Avukatlar için Yargl ve Temel Haklar Projesi, (Erişim Tarihi: 10.02.2020), https://www.ab.gov.tr/files/yargivetemelhaklar/yargi _ve_temel_haklar_kitap.pdf.

Avrupa Birliği Müzakere Sürecinde Yargı ve Temel Haklar Fasli (t.y.). (Erişim Tarihi: 17.05.2020), https://www.ab.gov.tr/files/pub/yayinlar/AB-

MuzakereSurecindeYargiveTemelHaklarFasli.pdf.

Avrupa Komisyonu, Türkiye 2014 Y1lı İlerleme Raporu (2014). Komisyon Tarafindan Avrupa Parlamentosuna, Konseye, Ekonomik ve Sosyal Komiteye ve Bölgeler Komitesine Sunulan Bildirim. (Erişim Tarihi: 02.10.2020), https://www.ab.gov.tr/files/ilerlemeRaporlariTR/201 4_ilerleme_raporu_tr.pdf.

Avrupa Komisyonu, Türkiye 2013 Y1lı İlerleme Raporu (2013), Komisyon Tarafindan Avrupa Parlamentosuna ve Konseye Sunulan Bildirim. (Erişim Tarihi: 01.10.2020), https://www.ab.gov.tr/files/2013\%20ilerleme\%20rap oru/2013_ilerleme_raporu_tr.pdf.

Avrupa Komisyonu, Türkiye 2015 Y1lı İlerleme Raporu (2015). Komisyon Tarafindan Avrupa Parlamentosuna, Konseye, Ekonomik ve Sosyal
Komiteye ve Bölgeler Komitesine Sunulan Bildirim. (Erişim Tarihi: 05.02.2020), https://www.ab.gov.tr/files/5\%20Ekim/2015_ilerlem e_raporu_tr.pdf.

Avrupa Komisyonu, Türkiye Düzenli İlerleme Raporu (2002). Türkiye’nin Avrupa Birliğine Katılım Sürecine İlişkin 2002 Yılı Illerleme Raporu. (Erişim Tarihi: 15.02.2020), https://www.ab.gov.tr/files/AB_Iliskileri/AdaylikSur eci/IlerlemeRaporlari/Turkiye_Ilerleme_Rap_2002.p df.

Avrupa Komisyonu, Türkiye Raporu (2018). AB Genişleme Politikasına İlişkin 2018 Bilgilendirmesi. (Erişim Tarihi: 02.03.2020), https://www.ab.gov.tr/siteimages/pub/komisyon_ulk e_raporlari/2018_turkiye_raporu_tr.pdf.

Avrupa Komisyonu, Türkiye Raporu (2019). AB Genişleme Politikasına İlişkin 2019 Bilgilendirmesi. Erişim Tarihi: 03.03.2020), https://www.ab.gov.tr/siteimages/birimler/kpb/2019 _trkiye_raporu-_tr.pdf.

Avrupa Topluluklar Komisyonu, Türkiye Düzenli İlerleme Raporu (2004). Türkiye'nin Katılım Yönünde İlerlemesi Hakkında 2004 Yll Düzenli Raporu. (Erişim Tarihi: 18.02.2020), https://www.ab.gov.tr/files/AB_Iliskileri/AdaylikSur eci/IlerlemeRaporlari/Turkiye_Ilerleme_Rap_2004.p df.

Bakkalcı, A.C. (2019). Avrupa Birliği-Türkiye İlişkileri Teorik Temeller-Uygulama-Tartışmalar. Ankara: Seçkin Yayınları.

Baltacı, C., Eke, E. \& Avcı, M. (2012). Türkiye-Avrupa Birliği İlişkilerinin Türk Anayasal Demokrasisi Üzerine Etkisi. C. Ü. Íktisadi ve İdari Bilimler Dergisi, 13 (2), 133-149.

Bianet (02. 08. 2001), Avrupa Birliği Temel Haklar Bildirgesi, (Erişim Tarihi: 17.02.2020), http://bianet.org/bianet/siyaset/3780-avrupa-birligitemel-haklar-bildirgesi.

Bilici, Nurettin (2013), Avrupa Birliği ve Türkiye, Ankara: Seçkin Yayıncılık.

Braud, P. (2011). Devlet: Hukuki Öğretinin İkilemleri, Gülçin Balamir Çoşkun (Çev.). İçinde: Cemal Bâli Akal (Derleyen), Devlet Kuramı (s.359-376). Ankara: Dost Kitabevi.

Ceritli, İ. (2012). Türk Kamu Yönetiminde Şeffaflaşma ve Hesap Verebilirliğe Yönelik Pozitif Dönüşüm, Dirençler ve Zayıflıklar: Geleceğin Gelenekle Dansı. İçinde: Ed. Kamil Kılınç ve Yalçın Urhan (Ed.), Şeffaf ve Hesap Verebilir Kamu Yönetimi Sетровуити (s.27-42), Ankara.

Çalış, Ş. H. (2008). Türkiye-Avrupa Birliği İlişkileri Kimlik Arayışl, Politik Aktörler ve Değişim. Ankara: Nobel Yayın Dağıtım.

Erdem, F. H. \& Çoşkun, V. (2009). Askeri Yarg1 ve Vesayet. SETA Analiz, (9), http://file.setav.org/Files/Pdf/askeri-yargi-ve-askerivesayet.pdf. 
Ergun, A.(2014). Hukuk Devleti İlkesi ve Yargının Bağımsızlığı-Tarafsızlığı Sorunu Kapsamında Ethem Sarıülük Davasının

Değerlendirilmesi. Ankara Barosu Dergisi, (4), 495522.

Erkiner, H. H. (2013). Yirmi Birinci Yüzyılda, Birleşmiş Milletler'in "Hukuk Devleti" ve "Hukukun Üstünlüğü” Yaklaşımı ve Bunun Uluslararası Hukuk Bakımından Yeri ve Değeri, İstanbul Üniversitesi Hukuk Fakültesi Mecmuası, 71(1), 353-380.

Esen, S. (2016). 2016 Anayasa Değişiklik Teklifinin Değerlendirilmesi. Ankara Barosu Dergisi, (4), 4573.

Euronews (15.07.2019). Verilerle 15 Temmuz Sonrast ve Ohal Süreci. (Erișim Tarihi: 20.03.2020), https://tr.euronews.com/2019/07/12/verilerle-15temmuz-sonras-ve-ohal-sureci.

Gemalmaz, M. S. (2005). Ulusalüstü Insan Haklar Hukukunun Genel Teorisine Giriş. İstanbul: Legal Yayıncılık.

Gönenç, M. L. (2018). Uygulamada Cumhurbaşkanlığı Hükümet Sistemi. Türkiye Ekonomi Politikalar Araştırma Vakfi, 1-6. (Erişim Tarihi: 08.05.2020), https://www.tepav.org.tr/upload/files/15268844867. Uygulamada_Cumhurbaskanligi_Hukumet_Sistemi. pdf 1-6).

Gözler, K. \& Kaplan, G. (2011). Idare Hukukuna Giriş. Bursa: Ekin Basın yayın Dağıtım.

Gözlügöl, S. V. (2013). Uluslararası Hukuk Boyutuyla Hukukun Üstünlüğü. Gazi Üniversitesi Hukuk Fakültesi Dergisi, 17(1-2), 1423-1453.

Gözübüyük, A. Ş. (2013). Hukuka Giriş ve Hukukun Temel Kavramlart. Ankara: Turhan Kitabevi.

Gözübüyük, Ş. (2003). Anayasa Hukuku. Ankara: Turhan Kitabevi.

Günday, Metin (2017). OHAL, İhraç KHK'leri ve Hukuki Durum. Ankara Barosu Dergisi, (1), 29-38.

Güneş, M. A. (2016). Avrupa Birliği’nin Temel Değerleri Üzerine. Türkiye Barolar Birliği Dergisi, (125), $307-$ 340 .

Gürel Günal, G. \& Günal, A. (2016). Avrupa Birliği Beşinci Genişleme Sürecinde İşsizlik Oranlarının Belirleyicileri Mekânsal Ekonometri Analizi. Ege Stratejik Araştırmalar Dergisi, 7(2) , 237-252.

Hürriyet (10.08. 2004). Çingene Haklarl yargl yolunda. (Erişim Tarihi: 17.02.2020), https://www.hurriyet.com.tr/gundem/cingenehaklari-yargi-yolunda-248128.

Kaboğlu, İ. O. (2016), Anayasa Hukuku Dersleri (Genel Esaslar). İstanbul: Legal Kitabevi.

Kahraman, M. (2011). Hukuk Devletine Katkıları Bakımından Kamu Denetçiliği. Mustafa Kemal Üniversitesi Sosyal Bilimler Enstitüsü Dergisi, 8(16), 355-373.
Karluk, R. \& Tonus, Ö. (2004). Avrupa Birliği'nin Genişleme Perspektifi'nde Türkiye'nin Yeri. Türkiye Iktisat Kongresi (05-09 Mayls 2004). http://www.geocities.ws/ceteris_tr2/karluk_tonus.do c.

Karluk, R. (2014). Avrupa Birliği, Kuruluşu, Gelişmesi, Kurumları. İstanbul: Beta Basım Yayın.

Kurnaz, I. (19.02. 2020). “Olağanüstü Hal, Sabit Bir Hale Getirilmiştir”: Rıza Türmen İle Söyleşi. Birikim. (Erişim Tarihi: 10.03.2020), https://www.birikimdergisi.com/guncel/9948/olagan ustu-hal-sabit-bir-hale-getirilmistir-riza-turmen-ilesoylesi.

Küçük, A. (2004). Hukuk Devleti, Demokrasi ve Temel Hak ve Hürriyetlerin Güvencelenmesi. Liberal Düşünce, (35), 201-219.

Magen, A. (2016). Cracks in the Foundations: Understanding the Great Rule of Law Debate in the EU. Journal of Common Market Studies, 54(5), 1050-1061

Milliyet (31.05.2014). AB'den Sert Taksim Tepkisi: Aşırı Güç Kullanımını Kınıyoruz.(Erişim Tarihi: 22.05.2020),

https://www.milliyet.com.tr/gundem/ab-den-serttaksim-tepkisi-asiri-guc-kullanimini-kiniyoruz1716867.

Özbudun, E. (2016). Türk Anayasa Hukuku, Ankara: Yetkin Yayınları.

Özdemir, H. \& Çiftlikçi, A. (2015). Avrupa Birliği (AB)'ne Üyelik Sürecinde Türkiye'de Hukuk Devletinin Dönüşümü: Helsinki Zirvesi’nden Günümüze İç Hukukta Yapılan Düzenlemeler Üzerine. Fırat Üniversitesi Sosyal Bilimler Dergisi, 25(1), 123-144.

Özdemir, H. (2012). Avrupa Mantığl: Avrupa Bütünleşmesinin Teori ve Dinamikleri. İstanbul: Boğaziçi Üniversitesi Yayınevi.

Özkazanç, A. (2015). Devletin Örgütlenmesi. İçinde: Yüksel Taşkın (Ed.), Siyaset: Kavramlar, Kurumlar (s.139-170), İstanbul: İletişim Yayınları.

Özkul, F. (2016). Anayasalarımızda Yargının Bağımsızlığı ve Tarafsızlığı. Ankara Barosu Dergisi, (3), 201263.

Öztürk Yılmaz, N.(2007), “5543 Sayılı İskân Kanunu Hükümleri Uyarınca Türk Vatandaşlığının Kazanılması", Türkiye Barolar Birliği Dergisi, (68), 241-264.

Pech, Laurent (2012), Rule Of Law a Guilding Principle of The Eurupean Union's External Action, CleerWorkingPapers, https://www.asser.nl/media/16 32/cleer2012-3web.pdf.

Polater, Y. Z. (2016). Bilgi Edinme Hakkının Sinırları ve Devlet Sirrı. Türkiye Barolar Birliği Dergisi, (122), 99-140.

Sander, O. (2005). Siyasi Tarih 1918-1994. Ankara: İmge Kitabevi. 
Selçuk, S. (1999). 1999 - 2000 Adli Yılı Açış Konuşması, (Erişim Tarihi: 15.06.2020), https://www.yargitay.gov.tr/documents/acilisKonus ma/1999-2000.pdf.

Soyaltın Colella, D. (2020). Avrupa Birliği’nde Hukukun Üstünlüğü Krizi Üye ve Aday Ülkelere Yönelik Önleyici Politikaların Siyaseti. Pamukkale Üniversitesi Sosyal Bilimler Enstitüsü Dergisi, (38), 69-85.

T.C. AB Bakanlığı: AB'ye Genel Bakış (t.y.). (Erişim Tarihi: 15.05.2020), https://www.ab.gov.tr/files/rehber/02_rehber.pdf.

T.C. AB Bakanlığg: Siyasi Reformlar-I (t.y.). (Erişim Tarihi:

02.03.2020),https://www.ab.gov.tr/files/rehber/04_re hber.pdf.

T.C. Başbakanlık Avrupa Birliği Genel Sekreterliği (2007). Türkiye'de Siyasi Reform Uyum Paketleri ve Güncel Gelişmeler. (Erişim Tarihi:01.02.2020), https://www.ab.gov.tr/files/pub/tsr.pdf.

T.C. Dışişleri Bakanlığı Avrupa Birliği Başkanlığı (2019). AB Yapısı ve Işleyişi. (Erişim Tarihi: 25. 02. 2020), https://www.ab.gov.tr/3.html.

T.C. Dışişleri Bakanlığı Avrupa Birliği Başkanlığı (2020a). Avrupa Birliği Tarihçesi. (Erişim Tarihi: 15.02.2020), https://www.ab.gov.tr/105.html.

T.C. Dışişleri Bakanlığg Avrupa Birliği Başkanlığı (2020b). Türkiye-AB Ilişskilerinin Tarihçesi. (Erişim Tarihi: 01.03.2020), https://www.ab.gov.tr/turkiye-abiliskilerinin-tarihcesi_111.html.

T.C. Kamu Denetçiliği Kurumu (2016). Kopenhag Kriterleri. (Erişim Tarihi: 15.01.2020), https://www.ombudsman.gov.tr/uluslar-arasimevzuat/index.html.

Tanör, B. \& Yüzbaşığlu, N. (2012). 1982 Anayasasına Göre Türk Anayasa Hukuku. İstanbul: Beta Basım Yayın.

TBMM (2004). TBMM'nin AB Uyum Karnesi Pekiyi. (Erişim Tarihi:15.02.2020), https://www.tbmm.gov.tr/develop/owa/web_basin_a ciklamalari.aciklama?p1=14602.

TBMM Haber Dergisi (1997-1998). Dış İlişkiler, Sayı:59. (Erişim Tarihi: 15.05.2020), https://www.tbmm.gov.tr/develop/owa/meclis_bulte ni.bulten_sayfa?psayi=59\&psayfa=9.

Teziç, E. (2012). Anayasa Hukuku (Genel Esaslar). İstanbul: Beta Basım Yayın.

Tunç, H. (2018). Anayasa Hukuku Genel Esaslar (Ders Kitabl). Ankara: Gazi Kitabevi.

Türkiye Katılım Ortaklığı Belgesi (2001). Türkiye Cumhuriyeti Ile Katılım Ortaklı̆̆ında Yer Alan Ilkeler, Öncelikler, Ara Hedefler ve Koşullara İlişkin 8 Mart 2001 tarihli KONSEY KARARI. (Erişim Tarihi:

01.02.2020)
https://www.ab.gov.tr/files/AB_Iliskileri/AdaylikSur eci/Kob/Turkiye_Kat_Ort_Belg_2001.pdf.

Türkiye Katılım Ortaklığı Belgesi (2003). Türkiye İçin Katılım Ortaklığ Belgesi (14 Nisan 2003 Tarihinde AB Konseyi Tarafindan Kabul Edilen Nihai Metin). (Erişim Tarihi: 15.02.2020),https://www.ab.gov.tr/files/AB_Iliskiler i/AdaylikSureci/Kob/Turkiye_Kat_Ort_Belg_2003.p df .

Türkiye Katılım Ortaklığı Belgesi (2006). Türkiye İle Katılım Ortaklı̆̆ Belgesinde Yer Alan İlkeler. Öncelikler ve Koşullara İlişkin 23 Ocak 2006 Tarihli Konsey Karart. (Erişim Tarihi: 17.02.2020), https://www.ab.gov.tr/files/AB_Iliskileri/AdaylikSur eci/Kob/Turkiye_Kat_Ort_Belg_2006.pdf.

Türkiye Katılım Ortaklığg Belgesi (2008). 2006/35/EC Sayılı Kararın Feshine ve Türkiye ile Katılım Ortaklığının Kapsadı̆̆ İlkeler, Öncelikler ve Koşullara Dair Bir Konsey Kararı. (Erişim Tarihi: 15.02.2020), https://www.ab.gov.tr/files/AB_Iliskileri/AdaylikSur eci/Kob/Turkiye_Kat_Ort_Belg_2007.pdf,

Yıldız, H. (2013). Hukuk Devleti’nin Gelişim Sürecinde Mülk Devleti ve Polis Devletinin Yeri. Dokuz Eylül Üniversitesi Hukuk Fakültesi Dergisi, 15(2), 211 230.

Yılmaz, A. (2001). Çă̆daş Siyasal Akımlar (Modern Demokraside Yeni Arayışlar). Ankara: Vadi Yayınlar.

Yücel, B. (2012). 5982 Sayılı Anayasa Değişikliği Kanunu'nun 1982 Anayasası'nın "Hukuk Devleti" Anlayışına Etkisi. Türkiye Barolar Birliği Dergisi, (100), 83-96.

2001 Yılı Ulusal Programı (2001). AB Müktesebatının Üstlenilmesine Ilişkin Türkiye Ulusal Programı.(Erişim Tarihi: 15.02.2020), https://www.ab.gov.tr/195.html.

2003 Y1lı Ulusal Programı (2003). AB Müktesebatının Üstlenilmesine İlişkin Türkiye Ulusal Programı. (Erişim Tarihi: 15.02.2020), https://www.ab.gov.tr/_196.html.

2008 Y1lı Ulusal Programı (2008). Avrupa Birliği Müktesebatının Üstlenilmesine Illişkin Türkiye Ulusal Programı. (Erişim Tarihi: 15.02.2020), https://www.ab.gov.tr/_42260.html.

5170 Sayılı Türkiye Cumhuriyeti Anayasasının Bazı Maddelerinin Değiştirilmesi Hakkında Kanun, (22.05.2004 Tarih, 25469 Sayılı T.C. Resmi Gazete).

6755 sayılı Olağanüstü Hal Kapsamında Alınması Gereken Tedbirler ile Bazı Kurum ve Kuruluşlara Dair Düzenleme Yapılması Hakkında Kanun Hükmünde Kararnamenin Değiştirilerek Kabul Edilmesine Dair Kanun, (24.11.2016 Tarih, 29898 Sayılı T.C. Resmi Gazete). 